\title{
Modern Coğrafi Düşüncede Mekân ve Yer Kavramlarının Teorik Temelleri Üzerine Bir Değerlendirme*
}

\author{
An Evaluation on Theoretical Foundations of Space and Place Concepts in Modern \\ Geographical
}

\author{
Selim BOZDOĞAN ${ }^{1}$ (D), Sedat BENEK ${ }^{2}$ (D) \\ ${ }^{1}$ YÖK Siyasi Coğrafya Doktora Bursiyeri, Harran Üniversitesi, Sosyal Bilimler Enstitüsü, Şanlıurfa, Türkiye \\ ${ }^{2}$ Prof. Dr., Harran Üniversitesi, Fen-Edebiyat Fakültesi, Coğrafya Bölümü, Şanlıurfa, Türkiye
}

ORCID: S.B. 0000-0001-8852-8974; S.B. 0000-0002-5221-9683

\begin{abstract}
Öz
Bu çalışmanın amacı, mekân ve yer kavramlarının düşünce tarihinde nasıl kuramsallaştırıldığı ve bunun coğrafi düşünceye etkilerini incelemektir. Günümüzde hem gündelik sözlüklerde hem de disiplin sözlüklerinde mekân ve yer, bazen birbiri yerine bazen de birbirinden tamamen farklı anlamlarda kullanılmaktadır. Coğrafya disiplininde de mekân ve yer kavramlarına dair farklı tanımlama biçimleri mevcuttur. Bu yüzden coğrafyada mekân ve yere dair farklı tanımlamaların anlaşılabilmesi için, her iki kavramın kullanılma biçimlerinin, beslendikleri epistemolojik gelenekleri analiz etmek elzemdir. Kavramsal, tarihsel ve teorik bir çalışma olması nedeniyle, nitel bir yöntem olan 'metin analizi' tekniğine başvurulmuştur. Sonuç olarak, bu çalışma mekân ve yere dair iki farklı perspektifin coğrafi düşünceye etkilerini incelemektedir. Birincisi, modern düşüncede ortaya çıkan 'mutlak mekân' anlayışıdır. İkincisi ise, mutlak mekân kavramına karşı fenomenologlar tarafından geliştirilen eleştirilerdir. Her iki düşünce geleneği üzerinden tartışılan mekân ve yer birbirinden ayrı olarak düşünülmüştür. Hem mutlak mekân anlayışını hem de yer yaklaşımlarının fenomenolojik boyutunun eleştirisi, genel anlamda, toplumsal mekân kavramından hareketle ortaya konulmaktadır. Bu bağlamda David Harvey ve Doreen Massey toplumsal mekân düşüncesinden hareketle mekân ve yerin ilişkisel boyutunu ön çıkarmaktadır. Bu ilişkide toplumsal bir ürün olarak mekân, yerlerin toplamını ifade eder. Yerlerin bir 'fark/toplam' olarak mekânı anlamlandırması uzunca bir süre göz ardı edilmiş bir olgudur.
\end{abstract}

Anahtar kelimeler: Mutlak Mekân, Yer, Mekân-Yer Iliş̧kisi

\section{ABSTRACT}

The purpose of this study is to examine how the concepts of space and place are theorized in the history of thought and their effects on geographical thought. Place and space are occasionally used interchangeably and sometimes have completely different definitions in today's dictionaries, both in ordinary and discipline dictionaries. There are different ways of defining the concepts of space and place in the discipline of geography. Therefore, in order to understand the different definitions of space and place in geography, it is essential to analyze the epistemological traditions that feed on the ways of using both concepts. As it is a conceptual, historical, and theoretical study, "textual analysis" technique, which is a qualitative method, has been used. In conclusion, this research looks at how two different perspectives on space and place affect geographical thinking. The first is modern thought's evolving notion of "absolute space." The second concern is phenomenologists' challenges of the concept of absolute space. Space and location are treated independently in different philosophical systems. The critique of the phenomenological dimension of both absolute space and place approaches is put forward, in general terms, based on the concept of social space. In this context, David Harvey and Doreen Massey highlight the relational dimension of space and place based on the idea of social space. In this relation, space as a social product expresses the sum of places. It is a phenomenon that has been ignored for a long time that places make sense of space as a "difference/total."

Keywords: Absolute Space, Place, Space-Place Relationship

*Bu çalışma Selim Bozdoğan'ın, Harran Üniversitesi BAP Koordinatörlüğü tarafından desteklenen 21075 numaralı doktora tez projesinden üretilmiştir.

Başvuru/Submitted: 06.03.2021 • Revizyon Talebi/Revision Requested: 19.04.2021 • Son Revizyon/Last Revision Received: 03.11 .2021 • Kabul/Accepted: 27.12.2021

Sorumlu yazar/Corresponding author: Selim BOZDOĞAN / selimbzdogan@gmail.com

Atıf/Citation: Bozdogan, S., \& Benek, S. (2021). Modern coğrafi düşüncede mekân ve yer kavramlarının teorik temelleri üzerine bir değerlendirme. Cografya Dergisi, 43, 177-195. https://doi.org/10.26650/JGEOG2021-892074 


\section{EXTENDED ABSTRACT}

Space and place are used both in daily use and in many meanings in discipline dictionaries. Although place and space are defined under different titles in Turkish, English, French, Italian, and German dictionaries, they are often used interchangeably. In the Dictionary of the Turkish Language Association, space is defined as a place. Place is defined as space. Location is also described as location and point. Although place and space are used interchangeably in English, French, Italian, and German dictionaries, space is generally described as three-dimensional floor-covering (res extensio) and place as point, location, and areas where human activities take place.

In disciplinary dictionaries, each discipline defines space and place according to its study object. In this context, space and place are discussed in different ways in the discipline dictionaries of Physics, Mathematics, Philosophy, Sociology, Political Science, Architecture, and Geography. In Physics and Mathematics dictionaries, space and place are clearly separated from each other. Geometric elements are used to explain space in the physics language. In the mathematical dictionary, space is discussed within the context of topology, whereas location is explained as a column. Space has a detailed definition in philosophy dictionaries, as well as definitions in Physics and Mathematics dictionaries. The concept of space is defined in the philosophy dictionary by Réne Descartes' concept of floor-covering (res extensio). Place is defined as a point or location in physical space. The definition of space and place in the architecture dictionary is also parallel to the explanations in the philosophy dictionary.

In the sociology dictionary, space is explained as the area where the formation and regeneration of different identities take place. There were no definitions of space and location in the Political Science dictionaries that were reviewed. However, when it comes to the agenda in Political Science with ideas, such as the nation-state, elections, democracy, and municipal governments, the concept of space develops organically. Place and place are used interchangeably in Turkish geography dictionaries. In English geography dictionaries, space and place are discussed separately. The place in these dictionaries implies a humanistic geographical perspective.

The epistemological traditions that feed both ideas are examined in this study in order to comprehend the definitions of place and space in both daily and discipline dictionaries. As a result, the "absolute space" perspective dominates dictionaries' definitions of space and place. Because, according to the absolute space concept, location is a position or point in space.

The first uses of the concept of space in the discipline of geography found meaning in the context of absolute space thought. The idea of absolute space is based on the mathematical-geometric planes of modern thinkers such as Galileo Galilei, Réne Descartes, and Isaac Newton. Absolute space thinking is based on the principles of digitization and calculation. Absolute space, articulated with spatialist, determinist, and positivist ideas, directly influenced geographical thought in the first half of the 20th century. This direct effect has emerged as "quantitative geography." The quantitative understanding of geography sees space as a place where statistical principles (regression, clustering, correlation, etc.) can be calculated and measured, and where human movements can be computed and measured. In other words, space is regarded as a surface on which the interactions between things can be observed. As a result, quantitative spatial knowledge is concerned with the development of repeatable spatial models based on statistical testing and mathematical theories.

Since the early 1900s, the attempt to explain space with mathematical theories has been criticized by phenomenologists. Phenomenologists such as Edmund Husserl, Martin Heidegger, Marleu-Maurice Ponty, Gaston Bacherlard explained their criticism of the absolute space with the relations between human, place, and environment. According to these phenomenologists, the relationship of individual senses-feelings with place connects human existence to space. The idea that the earth formed as a result of direct interaction between the body and space influenced geographers such as Edward Relph and Yu-Fi Tuan. Space, according to Relph and Tuan, is something fluid and abstract. As a result, people get rooted in the area and help to shape it. The goal of this research is to look at how the concepts of space and location have been hypothesized throughout history and how they have influenced geographical philosophy. In this perspective, three gaps in the history of thought's considerations of space and place can be identified. Therefore, this study examines both absolute space and phenomenology-based place approaches, based on the idea of social space. In other words, it is based on the "social space" idea, which includes a critical geographical perspective. As it is a conceptual, historical, and theoretical study, "textual analysis" technique, which is a qualitative method, has been used. 


\section{GİRIŞ}

Mekân ve yer, ilk düşünürlerden (Hesiodos, Platon, Aristoteles vb.) itibaren üzerine tartışılan bir konu olmuştur. Geleneksel düşüncede evrene yönelik her inceleme girişimi mekân ve yeri gündeme getirmiştir. Çünkü tarihsel süreçte; doğa, insan ile doğa ve toplum ile doğa arasındaki ilişkilerin anlaşılmasında, mekân ve yerin önemine her daim vurgular yapılmıştır. Bu yüzden mekân ve yerin anlaşılmasında, her iki kavramın teorik seyrini incelemek elzemdir. Dolayisıyla çalışmanın amacı, modern coğrafi düşüncedeki mekân ve yer tanımlamalarının beslendikleri epistemolojik gelenekleri ortaya koymaktır.

Bu çalışma, düşünce tarihinde mekân ve yer tartışmalarında üç temel kırılmaya dikkat çekmektedir. Birincisi Réne Descartes ile başlayan daha sonra Isaac Newton ve Immanuel Kant tarafından geliştirilen mutlak mekân yaklaşımıdır. Mutlak mekân yaklaşımı, daha sonra determinizm ve pozitivist felsefeyle iç içe geçerek mekândaki siyasal ve toplumsal olayların anlaşılması için bir yönteme dönüştürülmüştür. Bu felsefi geleneğin mekân ile ilgili ortaya koyduğu yaklaşımlar, bu çalışmada; Alexander von Humbolt, Richard Hartshorne, Fred K. Schaeler, William Bunge, Walter Christeller gibi coğrafyacılar üzerindeki etkisi tartışılmaktadır.

İkinci kırılma, fenomenolojinin 'mutlak mekân'a yönelik eleştirileridir. Yirminci yüzyılın başlarından itibaren Edmund Husserl'in rasyonalist, ampirist ve pozitivist düşünceye yönelik eleştirileri, mekân kavramının yeniden gündeme gelmesini sağladı. Martin Heidegger, Marleu-Maurice Ponty, Gaston Bacherlard gibi düşünürler, mutlak mekâna yönelik eleştirilerini; insan, yer ve çevre arasındaki ilişkilerden hareketle ortaya koydular. Bu fenomenologlara göre, rasyonalistlerin ifade ettiği gibi; insan beden ve zihin olarak birbirinden ayrı düşünülemez. Beden ve zihin birbirine içkindir ve bireysel duyu-hislerin yer ile olan ilişkisi, insan varoluşunu mekâna bağlamaktadır. Yer, bedenin mekân ile dolayımsız etkileşiminden meydana gelmiştir düşüncesi, Edward Relph ve Yu-Fi Tuan gibi coğrafyacıları büyük oranda etkilemiştir. Hümanist coğrafyacıların mekân ve yer ayrımında yer insan varoluşu çerçevesinde değerlendirmesi, Marksist ve feminist coğrafyacılar tarafından eleştirilmiştir.

Hümanist coğrafi anlayışa yönelik eleştiriler, bu çalışmada, üçüncü kırılma olarak ele alınmaktadır. Henri Lefebvre, David Harvey ve Doreen Massey gibi düşünürler, mekân ve yeri birbirleriyle ilişkisel bir düzlemde tartışmaktadırlar. Harvey ve Massey'e göre mekân ve yeri ayırmak; ekonomik, toplumsal ve siyasal süreçlerin yerin üretimindeki işlevlerinin göz $\operatorname{ard} 1$ edilmesine neden olmaktadır. Dolayısıyla bu çalışma, tarihsel süreçte ortaya çıkan üç kırılmayı mekân ve yer kavramları çerçevesinde tartışmaktadır. Diğer yandan mekân ve yer ayrımının gündelik ve disiplin sözlüklerindeki tanımlama biçimleri de düşünce tarihi bağlamında ele alınmaktadır.

Açıklayıcı bir araştırma olan bu çalışmada nitel bir yöntem olan metin analizi tekniğine başvurulmuştur. Metin analizi tekniği, eleştirel coğrafi bilimden hareketle düşünülmektedir. Yani hem mutlak ve nicel mekânın temellendiği rasyonel ve pozitivist anlayış hem de bireysel-duyu temelli yer yaklaşımının beslediği yorumlayıcı yaklaşımın eleştirisi, metin analizi tekniği üzerinden ortaya konulmaktadır.

\section{GÜNDELIKK SÖZLÜKLERDE MEKÂN VE YER}

Gündelik sözlüklerde mekân ve yer kavramlarının kullanılma biçimleri farklı şekillerde ortaya çıkmaktadır. Örneğin Türk Dil Kurumu Sözlüğü'nde (TDKS) mekân şu şekilde açıklanmaktadır: “(1) Yer, bulunulan yer; (2) ev, yurt; (3) gökbilimi, uzay”". Üç madde dört farklı anlama göndermede bulunmaktadır: 'Toprak, konum, adres ve boşluk'. Sözlükte mekâna dair üç maddenin vurgu yaptığı anlamalar (toprak, konum, adres ve boşluk) yer kavramı için de geçerlidir. Sözlükte yer kavramı on üç madde halinde açılanmaktadır ve yer, mekân kavramındaki açıklamalara benzer anlamlarda kullanılmaktadır: “(1) Bir şeyin, bir kimsenin kapladığı veya kaplayabileceği boşluk, mahal, mekân; (2) bulunulan, yaşanılan, oturulan bölge; (3) (coğrafya) yerküre; (4) durum, konum, vaziyet”" Görüldüğü gibi her iki kavram, birbiri yerine kullanılmakta ve farklı maddeler de iç içe anlamlarda açıklanmaktadır.

TDK sözlüğündeki mekân ve yere dair karmaşık açıklamalar, İngilizce Oxford Sözlüğü’nde daha karmaşık bir hal almaktadır. Oxford Sözlüğü'nde mekân (space) açıklamaları ile yer (place) açıklamaları hem aynı anlamda hem de birbirinden farklı şekillerde ortaya çıkmaktadır. Bu yüzden Dolores Hayden, İngilizcedeki yer tanımlamaları çokluğunu, aşırı doldurulmuş bir bavulun kapanmayan ağzına benzetmektedir (Hayden, 2014: 82). Bu bağlamda Sözlük'te mekân sekiz madde halinde açıklanmakla birlikte, bu çalışma bağlamında dört maddeye dikkat çekilmektedir: "(1) Dünya atmosferinin dışı; (2) boş alan; (3) her şeyin var olduğu ve hareket ettiği tüm alan; (4) belirli bir alan için kullanılabilecek bir yer, özellikle bir oda veya bina"”. Aynı sözlükte yer on beş madde halinde sıralanmakta ve özellikle bu çalışmada dört maddeye vurgu yapılmaktadır: "(1) Belirli bir konum, nokta veya alan; (2) belirli bir şehir, kasaba, bina; (3) bir 
yüzeydeki belirli bir alan, özellikle bir kişinin bedeni; (4) bir şeyin doğal veya doğru pozisyonu; (5) bir ev veya daire; bir kişinin evi"'. Dolayısıyla mekân ve yerin aynı anlamda kullanıldı̆̆ı maddeler olmakla birlikte aynı zamanda mekân ve yeri farklı anlamlarda (mekânın 1. ve 2. Maddesi) açıklayan maddeler de bulunmaktadır. Yine Almanca sözlükte de böyle bir durum söz konusudur. Almanca sözlükte mekân der Raum terimiyle ifade edilmektedir. Der Raum; “(1) -e yaşamak, kullanılabilir alan; (2) uzunluk, genişlik ve yükseklik" anlamlarını taşımaktadır. Yer olarak der Ort, "konum, site, durum, yer, insan yerleşimi, yerleşme, puan, bahşiş, kanton, baykuş, faaliyet alanı, sahne, yerellik, şehir, mekân, pozisyon”6 gibi birçok anlama gelmektedir.

Türkçe, İngilizce ve Almanca'da mekân ve yerin birbiri yerine kullanılmasına karşın Fransızca sözlükte mekân (espace) ve yer (place, lieu) arasında bir ayrımın olduğu görülmektedir. Fransızca sözlükte mekân 'geometrik bir düzleme' ilişkin özelliklerle açıklanmaktadır: “(1) Bir aralık içindeki belirli bir hacim; (2) etrafimızda ihtiyacımız olan boyut, alan veya hacim; (3) bir şey tarafından işgal edilen alanın kısmı veya iki şey -iki nokta- arasındaki mesafe; (4) boyut [étendue] (uzunluk-genişlikderinlik); (5) Belirli bir kullanım için tasarlanmış yüzey, genişlik, hacim; (6) gök cisimlerinin geliştiği Dünya atmosferinin ötesindeki çevre"’ . Fransızca sözlükte yer (place, lieu) ise: “(1) Yerleşik bir bölgede, binalarla çevrili açık kamusal alan; (2) Birisi tarafından işgal edilen alan; (3) yer, konum (emplacement); (4) Yer, yerellik, bina, yerel, vb. şeylerin ifade edilmesi" ${ }^{8 "}$ olarak açıklanmaktadır. Genel olarak Fransızcada mekân (espace), uzayda üç-boyutlu yer kaplama anlamında kullanılırken, yer (place, lieu) ise bu üç boyutlu uzamdaki 'konum' olarak açıklanmaktadır. İtalyanca sözlükte de mekân (spazio) ve yer (luogo, posto) birbirinden ayrı ve mekân, yeri de kapsamına alacak şekilde açıklanmaktakdır .

Gündelik sözlüklerde mekân ve yere dair yukarıda yapılan tartışmanın bu çalışma açısından önemi; 'yerin mekânda bir konum işgal etmesi'ne dönük yapılan tanımlamaların 'mutlak mekân’ yaklaşımıyla olan ilişkisidir. Çünkü bütün sözlüklerde mekân, yeri kapsamına alan makro ölçekte bir tanımlanmayı içermektedir. Buna bağlı olarak mekân kavramına eşlik eden iki terim daha ortaya çıkmaktadır: Uzam ${ }^{10}$ ve Uzay ${ }^{11}$. Uzam, cisimlerin 'uzay'da kapladıkları 'yer'dir (Hançerlioğlu, 1985: 65). Buna göre bir şey 'fiziksel mekân'da yer-kapladığında, kapladığı 'yer', mekânın bir kısmını oluşturmaktadır. Dördüncü başlıkta da görüleceği gibi, yerin mekânda bir konum olarak sergilenmesi, René Descartes'ın 'mutlak mekân' yaklaşımını yansıtmaktadır. Yer olarak konum, koordinatlar düzleminde hesaplanabilir bir mantığı ön plana çıkarmaktadır. Dolayısıyla günümüzdeki gündelik sözlüklerde yer, mekânda matematiksel ve geometrik bir konum dâhilinde açıklanmaktadır.

\section{DİSİPLİN SÖZLÜKLERİNDE MEKÂN VE YER}

Mekân kavramıyla doğrudan bağlantılı olan fizik, matematik, felsefe, mimarlık, sosyoloji, siyaset ve coğrafya gibi disiplinler, kendi çalıșma alanlarına göre mekânı tanımlarlar. Nasuhoğlu'nun (vd., 1983: 332) Fizik Terimleri Sözlüğü kitabının İngilizceTürkçe dizin bölümünde space, 'uzay' olarak çevrilmiştir. $\mathrm{Bu}$ sözlükte yer kavramına dair bir açıklama yapılmamıştır. Aynı şekilde Oxford Dictionary of Physics (2003: 544) sözlüğünde de mekân (space) uzay olarak iki madde halinde açıklanmıştır: “(1) Evrenin fiziksel fenomenlerin karşılıklı olarak üç dikey yöne doğru genişlemesini sağlayan bir özelliği; (2) Dünya atmosferinin dışında kalan evrenin diğer bölümü”. İlk tanıma göre mekân, boşluktaki cisimlerin genişlemesine olanak sağlayan evrenin bir özelliği; ikinci tanım ise, dünya dışındaki gezegenler ve gökcisimlerinin içinde bulunduğu boşluğu mekân olarak tanımlamaktadır. Sözlükte yer kavramına dair bir açıklama bulunmamaktadır.

Dictionary of Mathematics (2003: 220) sözlüğünde ise mekân (space), genellikle üzerinde topoloji bulunan bir küme veya bir yapı türü olarak açıklanmaktadır. Sözlükte mekân, matematiksel ve geometrik cisimlerin nitelikleriyle ilgili özellikleri ve konum, biçim ve büyüklüklerinin hesaplandığı soyut-kavramsal düzlemleri ifade etmek için kullanılmaktadır. Sözlükte yer ise şöyle tarif edilir: "Konumsal gösterimde tabanın belirli bir gücüne karşıllk gelen bir konum. Sütun olarak da bilinir" (Dictionary of Mathematics, 2003: 183). Bu yüzden yer, homojen mekânsal düzlemde geometrik bir gösterene ilişkindir.

Ahmet Cevizci'nin Felsefe Sözlüğ̈̈̈'nde mekân; “Varolanların içinde yer aldığı, tüm sınırlı büyüklükleri içine alan uçsuz bucaksız büyüklük. Boşluk, hiçlik durumu. Sınırsız ortam, sonsuz büyük kap ya da hazne. Üç boyutlu, yani eni, boyu ve derinliği olan hacim. Yer kaplama" (Cevizci, 1999: 583). Mekânın bu açıklaması, fizik ve matematik alanlarındaki mekân tariflerini de içeren, kapsamlı bir tanımlamadır. Felsefe sözlüğünde mekânın iki farklı özelliğine vurgu yapılmaktadır. Birincisi, mekân ölçülemez uçsuz bucaksız boşluktur; ikinci olarak mekân, cisimlerin kapladıkları yerlerin nicel ve ölçülebilir uzayıdır (Hançerlioğlu, 2006: 433). Orhan Hançerlioğlu'nun Felsefe Ansiklopedisi 7. Cilt'e göre yer ise, "uzayın bir bölümü... Felsefe anlamında cismin kapladığı uzay'ın parçasını dile getirir" (Hançerlioğlu, 1985: 303). 
Byran S. Turner'ın editörlüğünü yaptığı Cambridge Dictionary of Sociology sözlügü mekân1, cinsel kimliklerin nasıl inşa edildikleri ve bu kimliklerin kendilerini sosyal eylemde nasıl harekete geçirdikleri ve kendilerini nasıl gerçekleştirdikleri noktasında gündeme getirir. Sözlüğe göre, cinsel veya etnik kimlikler, her mekânda (ve her zaman) aynı şekilde inşa edilmez, yasalaştırılmaz ve gerçekleştirilmezler (Isın, 2006: 604). Bu yüzden mekân, sosyolojik incelemelerde çok önemli bir yere sahiptir. Diaspora, ulus ötesi kimlikler, kültürlerarası kozmopolit alanlarla ilgili sorular, mekân üzerinden sosyoloji düşüncesinin merkezi soruları haline gelmektedir (Isın, 2006: 605). Dolayısıyla sosyolojide mekân; cinsel veya etnik kimliklerin yerlere göre kurulumuna ve inşasına göndermede bulunmaktadır.

İncelenen siyaset bilimi, siyaset felsefesi, siyasal düşünce ve yönetim sözlükleri, doğrudan mekân ve yer kavramlarına yer vermedikleri göze çarpmaktadır ${ }^{12}$. Henri Lefebvre'nin ifade ettiği gibi mekân, her şeyden önce siyasaldır (Lefebvre, 2014). $\mathrm{Bu}$ bağlamda, siyaset biliminde mekân; devlet/ulus-devlet, egemenlik, demokrasi, vatandaşlık, otoriterizm, totalitarizm, seçimler, bölgeselcilik, jeopolitik, yerel yönetimler, yönetim sistemleri, federalizm ve kamusal/özel mekân gibi birçok terimle karşımıza çıkmaktadır. Devlet/ulus-devlet, yerel yönetimler, federal sistemler, bölgeselcilik ve seçimler, mekânsal taksimatlara bölünerek politikalara dâhil edilmektedir. Mekânsal anlamda devasa bir örgütlenme modeli olarak devlet, kendi içerisinde farklı idari coğrafi kademeler halinde yönetilmektedir. Devlet; federe yönetimler, özerk yönetimler, kantonlar, landlar ya da yerel yönetimler dâhilinde bölünmüş, mekânsal ölçeklerde varlığını icra etmektedir. Örneğin üniter bir devlet olarak Türkiye; il, ilçe ve köy olarak bölünmüş mekânsal bir yönetim modeline sahiptir. Her bir kademe kendine özgü mekânsal yapısı ve işleyişiyle tanımlanmaktadır. $\mathrm{Bu}$ bağlamda siyasal bir örgütlenme biçimi olarak devlet, kamusal hizmetleri coğrafi kademeler dâhilinde gerçekleştirmektedir. Özellikle ulusdevletlerde, siyaset ile mekân arasındaki ilişki mutlak mekân perspektifi üzerinden şekillenmektedir. Merkezi yönetim, taşradaki işleyişi ve örgütlenmeyi merkezde alınan kararlarla dizayn etmektedir. Bu yüzden 'yerel mekân' ile 'merkezi kamusal hizmetler' arasındaki ilişki hesaplama, ölçme ve istatistik'e dayalı olarak işlemektedir. Hesaplamayla Kartezyen geometri, sayılar ve matematiksel ölçümler, mekânı mutlak bir kategori içerisine sokmaktadır (Crampton ve Elden, 2006: 681).

Ansiklopedik Mimarlık Sözlüğ̈̈’nde yer başlığı altında iki madde bulunmaktadır: "1. Toprak kısmının yüzü. Zemin; 2. Arazi, Arsa" (Üngür, 2011: 7). Sözlükte mekân ise "insanı çevreden belli ölçülerde ayıran ve içinde eylemlerini sürdürmesine elverişli olan boşluk, boşun" (Üngür, 2011: 7) şeklinde tanımlanmaktadır. Mimarlık sözlüğündeki mekân ve yer tanımlamaları, felsefe sözlüklerindeki tanımlamalar ile koşutluk içermektedir.

Reşat İzbırak Coğrafya Terimleri Sözlüğü’nde mekân teriminin karşılığını, 'yer' olarak gösterir. Aynı sözlüğe göre yer, "yeryüzündeki bir alan"dır (İzbırak, 1976: 347). Ferruh Sanır Coğrafya Terimleri Sözlüğü’nde mekân terimine yer vermemektedir. Sanır (2000: 288) yeri ise, "yeryuvarlağı, yeryuvarı, dünya" şeklinde açıklamıştır. Dolayısıyla sözlüklerde mekân ve yer aynı anlamlarda kullanılmaktadır. Yani mekân ve yer; dünya ile ilişkili olarak jeolojik, topografik ve jeomorfolojik özelikleri açısından düşünülmektedir. Hayati Doğanay'ın Coğrafya Bilim Alanları Sözlü̆̆̈̈'nde ise mekân üç madde halinde açıklanır: "1. Bir kimsenin, bir nesnenin bulunduğu, bir olayın cereyan ettiği, oluştuğu yer. 2. Ev, konum. 3. Mekân tutmak; göçerliği terk edip, belli bir yere yerleşmek, yurt edinmek" (Doğanay, 2017: 357). Burada mekân, belli bir yeri işgal etme ya da belli bir konum bağlamında açıklanmaktadır. Doğanay devamında mekânın eş anlamlısının uzay olduğunu ifade etmektedir. Fakat Sözlük'te mekânın 1. ve 3. maddeleri uzay'dan çok uzam kavramını imlemektedir. Diğer yandan sözlükte yer ise beş madde halinde sıralanmaktadır:

1. Yaşayan güneş sistemi gezegeni. Yerküre, dünya. Güneş sisteminin beşinci büyük gezegeni. 2. Yerküre=Dünya'nın, deniz ve okyanus çanakları dışında kalan, katı yeryüzü (Yerin kabuk kısmının bir bölümü). 3. Ekip biçme, ekip dikme, üzerinde sosyal, kültürel ve endüstriyel yapılar yapılabilecek toprak, arazi, arsa. 4. Yöre, bölge, ülke. 5. Oturulan, yaşanılan, yurt edinilen topraklar; kent, mahalle, ev, cadde-sokak vb. (Doğanay, 2017: 587).

Sözlük'te mekân ve yer çok karmaşık bir şekilde ve mekân ve yerin bazı maddeleri (mekânın 1. maddesi ile yerin 4. maddesi) aynı anlamlarda kullanılmaktadır.

Yabancı sözlüklerden A Modern Dictionary of Geography ise mekânı şöyle tanımlamaktadır: Bir nesnenin kapladığı alan veya hacim ya da konumlar ve yerler arasinda bulunan yan mesafeler ve dünya yüzeyine dağılmış herhangi bir şeyin konumu (Witherick vd., 2001: 249). Bu açıklamaya göre mekân, şeylerin bulundukları yer ile bu şeyler ve yerler arasındaki dağılışlar ve ilişkilerin gerçekleştiği alandır. Sözlük, coğrafyanın temel 'dağılış ilkesi'nden hareketle mekânı açıklamaktadır. Coğrafyadaki dağılış ilkesi insan-mekân etkileşimini veri alır fakat sözlükteki tanım, daha çok 'ampirik-fiziksel' bir coğrafi 
bakış açısını yansıtmaktadır. Bu bakış açısı, mekânın aslında boş bir tuval/kap olduğu ve sosyal ilişkilerin de bu yüzey içinde gerçekleşen olaylar dizisi olduğu anlamını içermektedir (Hubbard, 2005: 41). Diğer yandan sözlükte yer kavramı tanımlanmamıştır.

Susan Mayhew Oxford Dictionary of Geography'de mekânı coğrafyanın kalbi olarak nitelendirmekte ve iki tür mekândan söz etmektedir:

Bir alanın kapsamı, genellikle dünyanın yüzeyi olarak ifade edilir. Bu anlamdan mekânsal terimi türetmektedir; ve mekânsal ilişkiler coğrafyanın kalbindedir. Açıkça farklı, gerçek ve nesnel alanı ifade eden mutlak mekân ve bir kişi veya toplum tarafından algılanan alan olan ve olaylar arasındaki ve olayların yönleri arasındaki ilişkiyi ilgilendiren göreceli mekânı ayırmak önemlidir (Mayhew, 2003: 562).

Mayhew'nun mekân tanımlaması, Isaac Newton'un 'mutlak mekân' ve 'göreceli mekân' ayrımını ortaya koymaktadır. Buna göre mekân iki anlama sahiptir: Birincisi mekân, mutlak dışsal hiçbir şeyle ilişkisi olmayan bir kavramdır. İkincisi, üzerinde hareket eden boyutların ölçüm ve konumlarının göreli olarak algılanışıdır. Buradaki görelilik mutlak değildir. Sadece mutlak mekânın hareketli boyutu ve ölçüsüdür. Buna göre mekân, yeryüzündeki fenomenlerin birbirleriyle olan uzaklıkları ve konumları ile bu fenomenlerin dağılışlarının ampirik-nicel hesaplanmasını içerir (Hubbard, 2005; Gregory, 2009). Sözlükte yer ise şöyle tanımlanmaktadır: "Dünya yüzeyindeki belirli bir nokta; insani değerlerle dolu bir durum için tanımlanabilir bir konum" (Mahyew, 2003: 471). Sözlükte yer, hümanist coğrafi bir perspektifle açıklanmaktadır. Yukarıda da görüldüğü gibi, mekân ve yer disiplinlerin çalışma alanlarına göre farklılık arz etmektedir. Bu yüzden "çoğu akademik kullanımda, insan coğrafyasında ya da diğer alanlarda mekân ve yer ya hiç ayrıt edilmez eşanlamlı kullanılır ya da biri öbürünü gölgede bırakıyor olarak açıklanır" (Agnew, 2005: 81).

Oxford Dictionary of Physics, Dictionary of Mathematics, Felsefe Sözlüğ̈̈, Ansiklopedik Mimarlık Sözlüğ̈̈, Oxford Dictionary of Geography, A Modern Dictionary of Geograph ve Coğrafya Bilim Alanlarl Sözlüğü sözlüklerindeki mekân ve yer açıklamaları 'mutlak mekân' yaklaşımı çerçevesinde ortaya çıkmaktadır. Buna göre mekân mutlak geometrik özelliklere sahiptir ve yer de mekânda bir konumdur. Siyaset Bilimi alanında da mekân kavramının işleyişi 'mutlak mekân' yaklaşımından hareketle düşünülmektedir. Crampton ve Elden'ın da vurguladığ1 gibi mekân siyaseti, örtük olarak (ve bazen açıkça) hesaplanabilir terimler çerçevesinde ortaya çıkmıştır (Crampton and Elden, 2006: 682). Özellikle coğrafi manzaranın sayısallaştırılabilir ve hesaplanabilir terimlerle nasıl çerçevelendiği bir sonraki başlıkta açıklanmaya çalışılmaktadır.

Ansiklopedik Mimarlık Sözlüğ̈̈, Reşat İzbırak ve Ferruh Sanır'ın Coğrafi Terimleri Sözlüğ̈̈’nde ise yer 'yeryüzünü' ifade edecek şekilde kullanılmaktadır. Ayrıca İzbırak ve Sanır yer ile mekânı özdeşleştirmektedir. Oxford Dictionary of Geography ve Coğrafya Bilim Alanları Sözlüğü’nde (yerin 3. ve 5. Maddesi) ise yer, toplumsal, ekonomik ve kültürel öğeler dâhilinde tanımlanmaktadır. Yere yönelik böyle bir açıklama, beşeri coğrafya alanının özellikle vurguladığı bir noktadır. The Dictionary of Human Geography'de yer, dünya yüzeyinin bir kısmının veya önceden var olan, farklılaşmamış mekânın insan tarafından işlenmiş bir dönüşümü olarak tanımlanır (Henderson, 2009: 540). Coğrafi düşüncede yerin insan ilişkileri tarafindan işlenmiş ve yapılandırılmış olduğuna yönelik açıklamalar 1970'lı yıllardan itibaren tartışılmaya başlanmıştır. Bu dönemde yer kavramı, coğrafya başta olmak üzere, diğer sosyal bilimler (felsefe, mimarlık, sosyoloji, antropoloji) alanında da temel tartışma konusu haline gelmiştir. Dolayısıyla hem gündelik sözlüklerde hem de disiplin sözlüklerinde mekân ve yere yönelik farklı tanımlama biçimlerinin anlaşılması için her iki kavramın düşünce tarihindeki teorik seyri daha sonraki bölümlerde incelenecektir.

\section{MODERN MUTLAK MEKÂN DÜŞÜNCESİ}

Modern düşüncede mekân, doğanın anlaşılmasında temel bir kavram olarak düşünülmektedir. Fizik ve matematik alanındaki ilerlemenin yaratmış olduğu bilimsel devrimler, doğanın matematiksel ölçümlerle hesaplanmasına dayandırılmıştır (Bkz: Santillana, 2013). Bu yüzden mekân tartışması, modern bir meseledir (Agnew, 2005: 83). Fakat mekânın 'mutlak ve matematiksel-geometrik' olarak tasavvur edilmesinin temelinde, Eukleides'in üç boyutlu geometrik-mekân düşüncesi yatmaktadır. Eukleides'in formüle ettiği şekliyle mekân; içinde hiçbir mutlak engelin olmadığı ve çevresinde herhangi bir dış sınırın olmadı $\breve{g}_{1}$ bir uzayın kavramsallaştııılmasıdır (Baker, 2003: 39). Eukleides geometrik-mekânı; 'nokta, çizgi, düz çizgi, yüzey, düzlem, düzlem açı, dik açı, şekil, çember ve paralel düz çizgiler' gibi temel kavramlarla düşünmektedir. Mekânın 'nokta, çizgi, düz çizgi vb.' kavramlarla anılması, mekânın homojenliğine bağlılığı gerektirir ve bu da mekânda hareket eden figürlerde bir değişikliğin olmadığı anlamına gelir (Berlinski, 2013: 47). Buna göre mekân "şeylerin üç boyuta yayıldıkları ve yer değiştirmelerine karşın özdeşliklerini korudukları homojen 
ortamdır" (Ponty, 2010: 20). Bu bağlamda Eukleidesyen mekân, 'geometrik' bir düzleme ilişkindir. Eukleides'in geometrikmekân düşüncesi, René Descartes'tan Isaac Newton ve Immanuel Kant'a kadar önemli bir entelektüel geleneği etkilemiştir.

René Descartes Meditasyonlar kitabındaki amacını, insanları kuşkulardan kurtarmak olarak belirler. Descartes'a göre, kuşku uyandırmayan temel hakikat 'aritmetik ve geometrik' düşünümsellikte bulunur (Descartes, 2015: 20). Aritmetik ve geometri salt zihinsel düşüncenin bir sonucu olduğu için şüphe içermemektedir. Fakat doğabilim, gökbilim, hekimlik ve öteki bilimler, yani bileşik yapıdaki şeyleri konu edinen bilimler kuşku içerir (Descartes, 2015: 28). Dolayısıyla sanılar, algılar ve duyum temelli bilgiler kuşkunun kaynağı olarak düşünülmektedir. $\mathrm{Bu}$ bağlamda Descartes, felsefe tarihinde Kartezyen düşünce olarak ifade ettiği 'zihin ve bedeni'i (özne/nesne, ruh/yerkaplama, res cogitans/res extensio) birbirinden ayırmaktadır. Zihin, salt fikirlere yönelik bir soruşturmayı içerirken; beden, duyumlara yönelik edimleri kapsamaktadır. Descartes 'beden'i şöyle açılar:

Beden deyince, herhangi bir biçimde sınırlanabilen, bir yerle çevrelenebilen (belirli bir biçimi ve konumu olan) ve bir mekân içindeki bütün öteki bedenleri dışlayacak şekilde doldurabilen, dokunularak, görülerek, işitilerek, tadılarak ya da koklanarak algılanabilen ve birçok şekilde hareket edebilen, ama kendi kendine değil, başka bir şeyin dokunmasıyla hareket edebilen, her şeyi kastediyorum (Descartes, 2015: 36).

Descartes'a göre beden, üç-boyutlu mekânda yer-kaplamadır. Bu yüzden mekân içindeki üç-boyutlu cisimlere yönelik kesin bilgiye 'geometri' ile ulaşılabilir. Descartes'a göre mekânsal uzam salt zihinsel formlara göre işleyen geometrik bir hesaplama yöntemiyle bilinebilir. Bu yüzden zihin, geometrik-mekândaki nesnelerin doğasına ilişkin ussal kavrayışının mükemmel bir gücüdür (Baker, 2003: 56).

Descartes, yer-kaplama yani beden ile mekân arasında bir özdeşlik kurar ve maddenin uzamı ile mekânı özdeşleştirir:

Mekân ya da iç yerin uzamı hiçbir zaman cismin uzamından ayrımlı değildir. Nasıl bir cismin, uzunluk, enlilik, derinlikçe uzamlı olmasından, bir töz bulunduğunu çıkarıyorsak (çünkü bir şey olmayan bir uzamın olamayacağını açıklıkla anlıyoruz) aynı yolla boş varsayılan mekâna ilişkin de aynı sonucu çıkarmamız gerekir. Mademki bu mekânda uzam vardır, öyleyse onda zorunlu olarak töz de bulunmaktadır...” (Descartes, 2007: 110111).
Descartes'a göre boşluk hacmi imkânsız kıldığ1 için boş mekân yoktur. Bu yüzden mekân maddi cisimden başka bir şey değildir. "Çünkü gerçekte, mekânı oluşturan uzunluk, enlilik ve derinlikçe uzam, cismi de oluşturur” (Descartes, 2007: 107). Burada mekân, basit bir yere sahip olan maddi cisim mefhumuna göre düzenlenir (Whitehead, 2018: 27). Bu durumda maddi bir cisim olarak bir yerde bulunma, mekândaki maddi cisimler arası ilişki ve bağlantıların göz ardı edilmesine neden olmaktadır. Çünkü Descartes'a göre yer, mekândaki bir konumdur. "Yer, büyüklük ve şekilden ziyade, daha kesin olarak; durumu (situation) gösterir" (Descartes, 1988: 86).

Descartes'a göre mekânda yayılım sayısallaştırmayl/nicelliği zorunlu kılmaktadır. Çünkü yer kaplama ya da yayılım geometrik bir 'alan' uzanımı anlamına gelmektedir. Bir şeyin ne kadar alan kapladığı, büyüklüğünün ve genişliğinin ne olduğuna ilişkin sorular geometrik özellikler içermektedir. Descartes için doğa ya da evren bütünle parçaların matematiksel oranlarına dayanmaktadır. Çünkü doğadaki bütün cisimler tek bir maddi tözden çıktıkları için cisimler arası farklılıklar da ancak sayısallaştırma ile ortaya konulabilir. Diğer yandan cisimlerin mekânda kapladığı alanların hesaplanması hareketi de varoluşsal bir zorunluluk olarak ortaya çıkarmaktadır. "Çünkü onda seçik olarak gördüğümüz tüm özellikler, onun bölünebilir, bölümlerine göre hareket edilebilir ve bölümlerin hareketiyle oluşabildiğini gördügü̈müz tüm çeşitli durumları alabilir olmasıyla ilgilidir" (Descartes, 2007: 114; Descartes, 1989: 106; Descartes, 2015: 60). Descartes için üç-boyutluluk; biçim, konum ve hareket mekândaki maddi cisim yerlerinin anlaşılmasındaki temel kavramlardır. Descartesçı kuramda "mekân, statik fakat hareket edebilen nesnelerin ve davranışlara ait dinamik akışların mutlak bir konteyneri olarak düşünülmüştür” (Glesson, 1996: 90).

Descartes'ın mekân ile maddenin özdeş ve yayılım/uzanım bakımından yer kaplama olarak açıklaması, Isaac Newton (16431727) tarafindan eleştirilmiştir. Newton'a göre mekân, kendi doğası içinde dışsal herhangi bir şeyle ilişkisi olmaksızın aynı ve hareketsiz kalmaktadır (Maudlin, 2012: 13). Mekânın içeriğinden bağımsız olarak zorunlu ve sonsuz olduğunu ifade eden Newton'a göre mekân, tüm diğer varlıkların koşulu olan zorunlu yapıdır. "Mekân kendi içinde bir varlık olması anlamında, kendini işgal eden nesnelerden ve olaylardan bağımsız, bu nesneleri ve olayları içeren ve onlardan ayrı güçlere sahip olması bakımından mutlaktır" (Agnew, 2005: 83). Descartes mekânı cismin yayılımına bağlı olduğunu ifade etmekteydi. Newton'a göre ise mekân kendinde mutlaktır ve her yerde sonsuzluğa uzanmaktadır. Bu bağlamda mekândaki şeyler ile mekânın kendisi arasında herhangi bir bağlantı bulunmamaktadır. 
Descartes'da mekân, yer kaplamaya bağlı olarak mutlak iken, Newton'da ise mekân 'kendinde' mutlaktır. Dolayısıyla "söz konusu öğretilere göre mekân, doğal dünyanın her şeyi kuşatan muazzam ilişkisinin dayanağıydı" (Whitehead, 2018: 28). Bu ilişkide mekân; içi nesnelerle dolu ve nesnelerin kapladıkları alan, nesnelerin yer değiştirmeleri ve nesnelerin hareketleriyle birlikte hesaplanan bir konteynerdir.

Descartes ve Newton'un mutlak mekân anlayışına karşıt bir görüş, Gottfried Leibniz (1646-1716) tarafindan geliştirilmiştir. Leibniz'e göre mekân bağıntısaldır ve mekânın hem öznel hem de nesnel yanı olmakla birlikte, aynı zamanda psikolojik ve ontolojik tarafları da bulunmaktadır. Buna göre mekân, bu mekânda bulundukları kabul edilen şeylerden bağımsız değildir (Lin, 2015: 1). Mekânın, bu mekânda bulunan şeylere göre herhangi bir mantıksal önceliği yoktur. "Leibniz'e göre mekân ya da uzam (extension), birlikte varoluşun düzen'i (order), ya da düzenler'i sonucu ortaya çıkan bağıntılardır” (Koç, 1984: 5). David Harvey, Leibniz'in 'bağlantısal mekân' düşüncesini daha da ileri taşıyarak mekândaki bağlantıların 'ilişkisel' boyutunu ön plana çıkarmaktadır (Harvey, 2009).

Newton'un kuramını temellendirmeyi amaçlayan Immanuel Kant (1724-1824), mutlak mekânın önsel bir algı kategorisi olduğunu öne sürmektedir. Kant bu yaklaşımını, Arl Usun Eleştirisi'nde dört belit halinde ortaya koymaktadır:

1. Uzay diş deneyimlerden türetilen görgül bir kavram değildir (...) 2. Uzay tüm dış sezgilerin temelinde yatan zorunlu bir a priori tasarımdır [A-24] (...) 3. Uzay genel olarak şeylerin ilişkilerinin diskursif ya da, söylendiği gibi, evrensel bir kavramı değil ama bir arı sezgidir [A-25] (...) 4. Uzay verili sonsuz bir büyüklük olarak tasarımlanır [B-40] (...) (Kant, 1993: 53).

Kant'a göre mekân, dişsal deneyimlerden ortaya çıkan ampirik bir kavram değildir. Bu yüzden mekân, duyu-algısal deneyime giren cisimlerden önce var olmaktadır. Kant geometrik mekânın özelliklerini sentetik ve a priori olarak belirlemektedir (Koç, 1984: 7). Bu yüzden mutlak mekân, saf önsel-sezgi kategorisinde bulunmaktadır. Mutlak mekân, temelini gündelik yaşam deneyimlerinden almayan saf aklın 'transendental' bir kategorisidir (Rukgaber, 2016: 434). Bu bağlamda Descartes, Newton ve Kant'n matematiksel ve a priori mutlak mekân görüşlerini Henri Lefebvre 'zihinsel mekân' olarak tanımlanmaktadır. Burada zihinsel mekân, fiziksel mekânla toplumsal mekânı kapsar fakat hem mekânın kendisini hem de mekândaki çok-katlllı̆̆ı ve ilişkisellikleri göz ardı etmektedir (Lefebvre, 2014: 37). Yukarıda mekânın mutlak olduğu görüşünün coğrafi yazındaki önemi 'determinizm' bağlamında ortaya çıkmaktadır. Çünkü determinizm yaklaşımında mekân, doğa ile ilişkili olarak düşünülmekte ve mekân 'verili' olarak 'doğa yasalarındaki' bir zorunluluğa bağlanmaktadır.

Mutlak mekân yaklaşımına göre, mekânda gerçekleşen olaylar doğa yasaları ile belirlenmiştir ve yine doğa yasaları dâhilinde anlaşılabilir. Buna göre hız, konum, yörünge ve hareket ile kuvvet terimleri, mekândaki cisimler arası ilişkileri ve etkileşimleri anlamak için temel kavramlardır. Buna bağlı olarak mekândaki cisimler, determinist ve mekanik (parça-bütün) bir bütünlük arzetmektedir. Mekân büyük bir makine gibi işlev görmekte ve parçalarının birbiri üzerindeki mekanik etkileriyle açıklanmaktadır (Cevizci, 1999: 584). Bu yüzden Pierre-Simon Laplace'ın determinist yaklaşımı, 'makine gibi çalışan evren' ilkesine dayanmaktadır. Evrenin bir makine gibi işlediğini ifade eden determinist düşüncenin sosyal olgulara da uygulanabileceğine dair önemli yaklaşımlar ortaya atılmıştır. Buna göre, mekânda gerçekleşen olaylar doğanın nedensel yasalarının bir sonucu ise, toplumsal düzen de kendi nedensel yasalarına bağlı olarak anlaşılabilir ve dönüştürülebilir. Dolayısıyla mekanik determinist yaklaşımın sosyal olgularla açıklanmasında Montesquieu (1689-1755)'nun önemli bir yeri vardır. Louis Althusser'e göre (2005: 19), 'toplumsal fizik' düşüncesini ilk ortaya atan kişi Montesquieu olmasa da olgulardan hareket ederek toplumsal yasalar çıkartan ilk kişi, Montesquieu'dur. İnsan ve çevre arasındaki ilişkiyi Kanunların $R u h u$ kitabında siyasal bir terminoloji ile ele alan Montesquieu, iklime bağlı olarak insan karakteri ve siyasal rejimleri sınıflandırır (Montesquieu, 2017). Aslında insan karakteri ile doğal çevre arasındaki bağlantıya yönelik vurgular Antik Yunan düşünürü Aristoteles'e kadar götürülebilir.

\section{Aristoteles Politika kitabında:}

Soğuk bölgede yaşayan ırklar ve Avrupa'dakiler cesaret ve tutku ile doludurlar, fakat beceri ve beyin güçleri biraz kıttır; bunda ötürü, genellikle bağımsız kalabilmelerine karşın, siyasal birlikleri ve başkalarına egemen olma becerileri yoktur. Öte yandan Asya ırkları hem beyinleri hem de becerileri vardır, ama cesaret ve iradeleri eksiktir; bu nedenle hep köleleştirilir uyruk olarak kalırlar. Coğrafyaca orta bir durumda bulunan Helen rrkı ise her ikisinden bir ölçüde pay almıştır (Aristoteles, 2014: 255).

Arsitoteles'e benzer bir yaklaşım, Ortaçağın son filozofu İbni Haldun tarafindan da dile getirilmektedir. İbni Haldun Mukaddime kitabında, iklim dönencelerini belirleyerek iklim ve insan karakteri arasındaki ilişkiyi umranın mekânsallığı 
üzerinden tartışmaktadır (Bozdoğan, 2019: 44). Fakat 18. ve 19. yüzyılda biyoloji alanındaki gelişmeler, insan ve çevre arasındaki determinist ilişkiyi bilimsel bir temele dayandırmaya çalışmıştır. Özellikle Charles Darwin ve Ernst Haeckel'in biyolojiye yönelik yeni çalışmaları coğrafi düşünceyi önemli oranda etkilemiş̧ir. Özgüç ve Tümertekin'in aktardığına göre; “doğanın güçlerinin birbirleriyle nasıl bir etkileşim içinde olduklarını ve coğrafi çevrenin bitki ve hayvanları nasıl etkilediğini... kısacası, doğanın birliğinin neyin sağladığını keşfedeceğim" (Özgüç ve Tümertekin, 2000: 196) diyen kişi Alexander von Humboldt'dur. Humboldt, Darwin gibi doğayı bir canlı yaşamı olarak ele almaktadır. Bu canlı yaşam, türler arası bir mücadele mekânıdır.

Humboldt'un mekân anlayışı, Kant'ın a priori mekân düşüncesine dayanır. Humboldt'a göre mekân yüzeyinin küçücük bir kısmına odaklanarak tüm mekânsal ilişkilerin tek bir hesapta birleştirilmesi mümkündür (Cresswell, 2013: 39). Richard Hartshorne da Kant'ın a priori mutlak mekân düşüncesinden hareket etmektedir. Hartshorne'da mekân verili bir kategori olduğundan yani 'belirli bir mekân' olduğu için, farklı bölgelerarası her türlü verinin entegrasyonunu ve sentezini yapmak mümkündür. Dolayısıyla Hartshorne'a göre mekân insan varoluşunun bir evrenseli, bir dış koordinat, birbirini dışlayan koordinatlardan oluşan boş bir ızgara, içinde nesnelerin var olduğu ve olayların meydana geldiği 'değişmeyen bir kutu'dur (Gregory, 2009: 708). Kısaca coğrafya, mutlak mekândaki şeylerin dağılışları ile ilgilidir. Bundan sonra asıl mesele, mekândaki şeylerin dağılışları ile ilgili 'bilimsel yasaların' oluşturulmasına kaymıştır. Bu bağlamda Fred K. Schaefer; coğrafyanın belirli özelliklerinin dünya yüzeyindeki mekânsal dağılımını yöneten yasaların formülasyonu ile ilgilenen bilim olarak kavranması gerektiğini vurgular (Schaefer 1953: 226). Schaefer'in bilimsel formülasyona yönelik bu vurgusu, teorik bir coğrafi anlayışın ortaya çıkarılmasına yöneliktir: Matematiksel mekân anlayışını ön plana çıkarır ve coğrafyaya yönelik evrensel yasalar çıkartılarak coğrafyanın bilimsel hale getirilebileceğini ifade eder (Schaefer 1953: 227). Sonuç olarak, mekânın hem şeylerin dağılışı noktasında hem de şeylere yönelik matematiksel yasaların oluşturulmasında mekân, verili mutlak bir kategori olarak değerlendirilmektedir.

Determinist düşüncede mekân, 'insan-çevre' ilişkisinde organik bütünlüğü sağlayan zorunlu bir yap1 olarak düşünülmektedir. Bu zorunlu yapı, önceden belirlenmiş ve belli fiziki yasalara göre işleyen bir düzene vurgu yapar. Burada mekân belirlenmiş doğal yasalar dâhilinde düşünüldüğü için mekâna yönelik bir inceleme gözlem, ölçüm ve hesaplama temelli evrensel yasaların oluşturulmasına dayandırılır. Örneğin toplumsal mekân örüntülerinde meydana gelen bir sorun, doğal çevreye yönelik bir inceleme ile anlaşılabilir. Bu yüzden mekân ‘doğal düzen anlamında' mutlaktır.

Evrensel doğal yasalardan hareketle toplumsal yapının da nesnelleştirileceği fikri, pozitivist düşüncede de ön plandadır. Pozitivist düşünceyi sistematik bir kuram haline getiren August Comte (1798-1857), Newton'un yerçekimi yasası ile doğayı açıklama girişimine benzer bir yol izleyerek, toplumsal evrenin gözlemlenmesi sonucunda da toplumsal yasaların çıartılabileceğini ileri sürmektedir (Comte, 2015). Comte'un pozitivist yaklaşımı, şeyleri doğuran nedenleri göstermeye yönelmemektedir. Şeylerin oluşum koşullarını kesin bir biçimde analiz etmeyi ve 'olağan art arda geliş' ve 'benzerlik' ilişkileriyle şeyleri yine bir birine bağlama iddiasına yoğunlaşmaktadır. Comte, doğal yaşamdaki art arda geliş ve benzerlikler aracılığıyla oluşturulacak yasaların kesinliğini, Newtoncu 'mutlak mekân' düşüncesinde bulur (Comte, 2015: 33). Comte fizik yasalarının yanında, bir de biyolojideki 'organizmalar arası bütünlük' ilkesine uygun olarak (Comte, 2015: 78/79), 'toplumsal bir düzen' arayışının mümkün olabileceğine dikkat çekmektedir. Buna göre, toplumsal somut olayların gözlemlenmesi yoluyla toplumsal yasalar ortaya konulabilir. Comte, gözlemlerin toplumsal yasalara dönüşmesinde; yöntem olarak 'gözlem, deney, karşılaştırma ve tarihsel analizin' önemine vurgu yapmaktadır (Comte, 2015).

Pozitivist bilimde mekân, olguların toplanması ve olgular arası ilişkilerin çözümlenmesine odaklanır. Burada mekân; soyut, matematiksel, sezgisel ve metafiziksel bir mantıksal düşünme biçimi olarak değil, doğrudan içerisindeki olayların gözlemlenmesine dayanan bir metodu içermektedir. Gözlemlenen olguların düzenlenmesi ve hesaplanmasinda olasılık, permütasyon ve kombinasyon gibi istatistiki hesaplamalar kullanılmaktadır (Gauch, 2016: 200-209). Bu yüzden pozitivizmin mekânı 'mutlak somut mekân'dır. Fakat mutlak somu mekân, mutlak soyut mekânı veri almaktadır. Nihayetinde hem 'soyut/zihinsel mutlak mekân' düşüncesi hem de pozitivist 'somut mutlak mekân' yaklaşımı, toplumsal olaylar ile mekân arasındaki karmaşık ilişkileri sayısal ve deneysel ilişkiler ile çözümlemektedir. Derek Gregory'e göre, coğrafyacılar pozitivist felsefeden nadiren doğrudan yararlandılar, ancak yine de onun bazı temel ilkelerini gevşek bir şekilde takip etmişlerdir (Gregory, 1978: 5).

Tim Cresswell’e göre "mekânsal bilimin yükselişi ve nicel devrim... 'genel coğrafya' için çok eski bir argümanın yeni bir versiyonuydu” (Cresswell, 2013: 81). Bu çalışma nicel mekân 
anlayışının 'matematiksel' yöntemini, düşünce tarihinde mutlak mekân tartışmalarındaki 'sayısallaştıma' metodunun bir devamı olarak okumaktadır. Bu bağlamda, Descartes ve Newton'da mekân, homojen iki şeyin koordinatlar düzleminde (harita) ölçüm ve hesaplamasına olanak sağlayan mutlak bir şeydir. Kant'ta mekân, a priori bir düzlemdir ve bilinebilirliği sentetik olması nedeniyle geometrik özelliklerle açıklamaktadır. Bu bağlamda Eukleides, Batlamyus, Descartes, Comte vb. düşünürlerin ölçme ve hesaplama temelli olarak ortaya koydukları 'nicel mekân' anlayışı, 1930 ve 1960 yılları arasında coğrafya alanında ifadesini bulmuştur (Smith, 2017: 110; Cresswell, 2013: 80). Ian Burton, nicel devrimin kökenlerini matematik, fizik, pozitivizm ve çevresel determinizmin mekâna yönelik açıklamalarında olduğunu ifade eder (Burton, 1963:153).

Yukarıda Schaefer'in mekânın matematikselleştirilmesine yönelik 'bilimsel kaygısı', William Bunge'da da var olan bir endişedir. Bunge, Schaefer'in sürekli olarak mekân bilimi ve mekânsal yasaların olasılıklarını savunduğunu belirtir (Bunge, 1979: 130). Bunge, öncelikle -bölgesel coğrafyaya karşı olarak'benzersizlik' kavramını bilimsel yöntemden kaldırılması gerektiğini savunur: "Yalnızca benzersizliğin tamamen reddedilmesiyle coğrafya çelişkilerini çözebilì" (Bunge 1962: 13; Akt: Cresswell, 2013: 87). 'Benzerlik' kavramı Comte düşüncesinde özellikle vurgulanan bir noktadır. Çünkü fizik yasalarının formülasyonunda 'benzersizlik', argümantasyon oluşturmada önemli zorluklar çıarmaktadır. Bu yüzden benzersizlik eleştirisi üzerinden genel ve evrensel bir 'mekân' bilimi oluşturulabilir. Bu bağlamda Bunge, Walter Christaller'ın 'merkezi yer teorisi'nin önemine dikkat çeker: "Merkezi yer teorisi olmasaydı, herhangi bir ana bilimler setinden bağımsız teorik bir coğrafyanın varlığına bu kadar vurgu yapmak mümkün olmazdı" (Bunge, 1962: 133; Akt: Cresswell, 2013: 89). Bunge'a göre, Christaller şehir mekânlarının büyüklüklerini, sayılarını ve dağılımlarını tahmin edecek önemli teorik-bilimsel bir açılım sağlamıştır: "Christaller, bir çiftçinin bir gün içinde bir pazara ne kadar seyahat edip geri dönebileceği öncülüyle başlar ve iç içe altıgenler türetir" (Bunge, 1979a: 171). Altıgenlerin mekânsal düzenleme dâhilinde ortaya çıkarmış olduğu yasalar, doğa yasalarından farklı görülmemektedir.

Walter Christaller, 'merkezi yer teorisi'nde tüm alanlar için geçerli olduğunu düşündüğü, aşağıdaki varsayımlardan yola çıkmaktadır:

- Sınırsız bir izotropik (tümü düz), homojen, sınırsız bir yüzey (soyut alan).
- Eşit dağılmış nüfus.

- Tüm yerleşimler eşit uzaklıktadır ve üçgen bir kafes düzeninde bulunur.

- Eşit dağıtılmış kaynaklar.

- Tam rekabet ve tüm satıcılar karlarını maksimize eden ekonomik insanlardır.

- Tüketiciler aynı gelir düzeyine ve aynı alıșveriş davranışına sahiptir.

- Tüm tüketicilerin mal ve hizmetler için benzer bir satın alma gücü ve talebi vardır.

- Tüketiciler, talep ettikleri işlevi sağlayan en yakın merkezi yerleri ziyaret ederler. Gidilecek mesafeyi en aza indirirler.

- Hiçbir mal veya hizmet sağlayıcısı fazla kar elde edemez (her tedarikçinin bir hinterland üzerinde tekeli vardır (King, 2021: 19/20).

$\mathrm{Bu}$ varsayımlara göre, merkezi yerlerin ticaret alanları aynı büyüklükte olmalıdır. Buradan hareketle Christaller bir dizi matematiksel formülasyon sonucunda iç içe geçen altıgenler oluşturmaktadır (Bkz: King, 2021: 19/25). Christaller teorisi, coğrafya ve ekonomi ile ilgili olmasına rağmen fizik bilimlerinde de eşit derecede geçerli olan ilkelere dayandığı konusunda ısrar etmektedir:

Bir çekirdeğin etrafındaki kütlenin kristalleşmesi, organik olduğu kadar inorganik doğada da, birbirine ait olan şeylerin düzeninin temel bir biçimidir - merkezi bir düzen. Bu düzen, sadece insanın hayal dünyasında var olan ve insanların düzen talep etmesiyle gelişen bir insan düşünce modeli değildir; aslında maddenin doğasında var olan modelin dıșında var olur. (Christaller 1966: 14, Akt: Cresswell, 2013: 90)

Ronald Abler, John S. Adams ve Peter Gould'in Spatial Organization kitabında bir dizi nicel mekân modellemesi ortaya atılmaktadır:

Bunlar, metrik sistemin oldukça tutarlı kullanımını ("akre" ve "inç" kelimeleri bazen görülse de), çizelgeleri içerir. Mekânsal ilişkilere matematiksel biçim veren, matematiksel ilişkileri göstermek için grafiklerin cömert bir kullanımı.... Pek çok etkili diyagram arasında "Viski İsyanı'na yol açan koşulları" gösteren bir diyagram vardır (Pitts, 1972: 431).

Nicel modellemelerin önemine dikkat çeken bir diğer coğrafyacı Peter Hagget'tir. Haggett'e göre modeller, mekânsal ilişkilerin genelleştirilebilir bir yeniden yapılanmasını sunmaktadır (Hagget, 1969: 31-90). 
Sonuç olarak nicel coğrafya anlayışı mekânı, istatiksel prensipler içeren (regresyon, kümelenme, korelasyon vb.) hesaplama ve ölçülme temelli mutlak bir alan olarak görmektedir. Burada mekân, şeyler arasındaki ilişkilerin gözlemlendiği bir yüzey olarak algılanmaktadır. Nicel mekân yaklaşımı, dünya yüzeyindeki şeyler arasındaki ilişkilerin istatiksel ve matematiksel teorilerle açılanabileceğini ve haritalanabilecek, modellenebilecek düzenli örüntülerin algılanmasına yoğunlaşmaktadır (Hubbard ve Kitchin, 2011: 5).

Reginald G. Golledge'ye göre nicel mekân anlayışındaki istatistiksel test etme ve matematiksel teorilerden hareketle tahmin edilebilir mekânsal modellerin oluşturulması fikri, bazı temel sorunlar içermektedir:

Peyzajın coğrafi değişkenliği genellikle ortadan kaldırılmıştır; ulaşımın benzer bir maliyetle her yöne eşit olarak mevcut olduğu varsayılmıştır; insanların mallar, hizmetler ve ürünler için aynı olanaklara ve tercihlere sahip olduğu varsayılmıştır; popülasyonların sabit olduğu, patlamadığı ve tek tip etnik veya kültürel üyeliklerden oluştuğu varsayılmıştır; ve karar verme ve seçim davranışının faydayı maksimize edecek şekilde gerçekleştiği varsayılmıştır. Ancak bu, ampirik gerçeklik dünyasından çok uzaktı (Golledge, 2008: 241).

Golledge, mekân içindeki insan 'davranışlarının' dayandırıldığı hipotezlerin ölçülebilir olduğu fikrine kuşkuyla bakmakta ve aşağıdaki üç temel noktanın incelenmesine dikkat çekmektedir:

(i) davranış üzerindeki yer ve peyzaj etkilerinin incelenmesi, (ii) çevresel tehlike oluşumuna ve insan davranışlarının devam etmesine ve mevcut bilgileri kullanarak gerekçelendirilmesi zor olan işgal kalıplarına yönelik tutumların incelenmesi, ve (iii) ekonomik ve mekânsal olarak rasyonel davranışın basitleştirici varsayımlarıyla çelişen karar verme ve seçim davranışlarının incelenmesi (Golledge, 2008: 242).

Nicel mekân anlayışındaki temel sorun, bilimsel nesnelcilik ve pozitivist ilkelerin sayısallaştırma ve hesaplama ilkelerini ön plana çıkararak insan ilişkileri (Tuan, 1971; Relp, 1976) ve toplumsal süreçleri (Lefebvre, 2014; Harvey, 2009; Smith, 2017; Soja, 2017) göz ardı etmesinde yatmaktadır. Özellikle 1970'li yıllardan itibaren tüm mekânsal ilişkilerin ölçülebilir olduğu fikri eleştirilmeye başlandı.

David Ley Geography without Man isimli çalışmasında, insanın çevreyle karşılaşmasının; zenginliği, alışveriş veya ticaret yolculuğunda mesafenin en aza indirilmesiyle ifade edilen rasyonel faaliyetin tek davranışsal varsayıma indirgendiğini ifade eder (Ley, 1980: 6). Çünkü farklı insan öznelliklerini ve yeni karşılaşma (affectus) biçimlerinin mekândaki yönelimleri, hesaplanamaz derecede karmaşı öğeler ve taktikler içermektedir (Certeau, 2008). Bu bağlamda, nicel mekân anlayışına yönelik eleştiriler; hümanist, Marksist, post-yapısalcı ve feminist coğrafyacılardan gelmiştir.

Mutlak mekân temelli nicel coğrafi anlayışın 'ölçme ve hesaplama' ilkeleri çerçevesinde açılklanması, John Pickles ve J. W. Crampton-Stuart Elden tarafından eleştirilmektedir. Pickles'e göre nicel mekân anlayışı, hareket özgürlüğü üzerinde daha fazla kısıtlamaya yol açmaktadır (Pickles, 2011: 18; Pickles, 1987: 30). Crampton ve Elden, 17. yüzyıldan itibaren aritmetiğin ve geometrinin mekân siyaseti üzerindeki önemli dönüşümleri, Micheal Foucault'nun kavramları (biyo-iktidar, yönetimsellik) üzerinden tartı̧̧maktadırlar (Crampton and Elden, 2006: 682). Foucault'nun 'biyoiktidar' kavramını, temelde, bir 'mekân müdahalesi' olarak düşünmektedirler. Bu yüzden hesaplama ve ölçme temelli nicel mekân anlayışı 'iktidarın gözü' olarak toplumsal yapıların düzenlenmesinde dönüştürücü bir işleve sahiptir (Elden, 2007: 562). Bu bağlamda düşünüldüğünde, mekânın hesaplama ve ölçme temelli politik düzenlemelere dâhil edilmesi, bireylerin gelecekteki yaşam alanlarının iktidar tarafindan denetlenmesi ve kontrol edilmesiyle sonuçlanmaktadır. Mekânın hesaplanması ve istatiksel ölçümler ile tek bir sonuçta ifade edilmesi, iktidar dispozitiflerinin biyo-politik bir stratejisi olarak işlev görmektedir (Foucault, 2016; Foucault, 2014). İmar çalışmaları ve çevre düzenlemeleri ile yerleşim yerlerinin belirlenmesi ve özellikle kent içinde faaliyet yürüten mekânlara dair yönetimsel (govermentality) planlamalar, 'bireylerin davranışları üzerinden davranışlarının kontrol edildiği' (Foucault, 2014; Foucualt, 2015; Elden, 2007a) bir 'soyut mekân' oluşturma stratejisi olduğuna vurgu yapılmaktadır (Lefebvre, 2014).

Cresswell'e göre, "nicel mekân yaklaşımı fiziksel dünyaya, yamaçlardan aşağı düşen kayalara veya akıntı yönünde hareket eden tortullara uygulandığında işe yarayabilir (ve çoğu zaman da işe yarar), ancak insanların insanlı̆̆ını/insan-oluşunu açıklayamaz" (Cresswell, 2013: 104). Bu bağlamda mutlak, matematiksel, geometrik ve nicel mekân yaklaşımına yönelik ilk eleştiriler fenomenoloji düşüncesinden gelmiştir. 'Yer' yaklaşımı fenomenoloji düşüncesine dayanmakla birlikte mekânsal bilime karşı 'yer'in önemine vurguyu yapan hümanist coğrafyacılardır. Hümanist coğrafyacılar, yerin mekânda sabit ve homojen bir konum olarak nicel modellemelere indirgenemeyeceğini savunmaktadir. 


\section{YER'İN FENOMENOLOJİK TEMELLERİ}

Fenomenolojinin kurucusu olarak görülen Edmund Husserl (1859-1938), The Crisis of European Sciences and Transcendental Phenomenology kitabında; Eukleides geometrisinden başlayarak Galileo, Descartes, Locke, Berkeley, Hume ve Kant'a kadar ki süreçte, düşünürlerin 'unuttuğu' 'yaşam-dünyası ontolojisini' [ontology of the life-world] ortaya çıkarmaya çalışmaktadır. Husserl'e göre mekânın ampirik sayılar, ölçü birimleri ve noktalar, çizgiler ve yüzeyler ile ele alınması bedenleri idealleştirmektedir. O 'mekânın ampirik figürler' dolaysıyla ideal-geometrik önermelere ve kanıtlara dönüştürüldüğüne dikkat çekmektedir (Husserl, 1970: 21). Husserl'e göre geometrik mekânın doğayı matematikselleştirmesi, epistemik özne (bilen) ile epistemik nesne (bilinen)'yi birbirinden koparmış ve insan öznelliğine ilişkin her türlü değere bütünüyle karşı olacak kadar, mekânı nesnelleştirmiş-bilimselleştirilmiş homojen bir dünyaya dönüştürmüştür. Fakat geometride vücutsuz bir zihnin önüne uzanan yekpare, homojen bir mekân düşüncesinin yerini, vücudumuzun özellikleriyle ve dünyaya firlatılmış varlıklar olarak bizim durumumuzla ilişki kuran, ayrıcalıklı doğrultuları olan heterojen bir mekân almıştır (Ponty, 2010: 26). Maurice-Merleau Ponty'e göre mekân, algılayan bedene içkindir.

Fenomenoloji düşüncesi, fenomenlerin 'verilmişlik' ve 'apaçlık'ının yaşam-dünyasının [Lebenswelt] bizatihi içinde olduğunu ön plana çıkarmaktadır: "Her zihinsel yaşantı ve her tür yaşantı, - gerçekleşir gerçeklemez- saf bir görme ve kavramanın nesnesi yapılabilir ve bu görmede yaşantı, saltık verilmişliktir" (Husserl, 2010: 25). Fenomenler saltık ve açık bir verilmişlik ile bedenle dolayımsız bir ilişki içerisindedirler. Bu dolayımsız ilişki, dünya-içinde olmanın zorunlu ön koşulu olarak ele alınmaktadır. Çünkü dünya-içinde-olma ya da yaşamdünyasında özne, her daim bir şeye yönelim [intentio] halindedir. "Bilgi yaşantıları, -özleri gereği- bir yönelim (intentio) taşırlar, bir şeyi kastederler, şu veya bu türdeki bir nesneyle bağlantı kurarlar" (Husserl, 2010: 45). Her tür deneyim biçimi kendi nesnesine yönelmektedir. "Gördüğümüzde, duyduğumuzda, hayal ettiğimizde, nefret ettiğimizde ya da korktuğumuzda, görüşümüz, duyuşumuz, hatırlayışımız, hayal edişimiz, düşünümüz, nefret edişimiz korkmamız bir şey hakkındadır. Bilinç buna yönelmişliği içerir, bu bir şeyin bilincidir" (Zahavi, 2020: 26) ve bu yüzden her daim bir içeriği bulunmaktadır. Dolayısıyla fenomenoloji; nesnelcilik, bilimsel nesnelcilik gibi mekânsal kavramsallaştırmalara karşı 'yaşam-dünyasının betimlenmesi’nin önemine dikkat çekmektedir.
Mekân, içinde şeylerin konum aldığı (gerçek veya mantıksal) ortam değil, şeylerin koyulmasını mümkün kılan aracıdır. Yani onu, içinde şeylerin yıkandığı bir tür eter gibi hayal etmek ve şeylerin ortak özelliği olarak soyutça kavramak yerine, şeylerin evrensel bağlantı kuvveti olarak düşünmeliyiz. O halde ya refleksiyon yapmam ve mekânı belli belirsiz, bazen şeylerin ortamı olarak bazen de ortak özellikleri olarak düşünürüm ve o zaman fark ederim ki bu bağlantılar ancak onları betimleyen ve taşıyan bir özne dolayısıyla yaşarlar, mekânsallaşmış mekândan mekânsallaştıran mekâna geçerim (Ponty, 2016: 331).

Ponty, beden-özne ${ }^{13}$ kavramsallaştırmasıyla (Ponty, 2016: 137) mekânı 'verilmişlik’ten dolayı yönelimselliğin gerçekleştiği yaşam-dünyasıyla ilişkilendirmektedir.

Mekân, bedenimizin ona katılmasiyla hissedilen bir fenomen olarak ortaya çıkmaktadır (Grange, 1985: 72). Yaşam-dünyasında öznenin çevre ile etkileşimi, hem bilimsel hem de akıl öncesi bir anlama sahiptir. Bu yüzden mekânsal boyutlar, pratik ve somut referanslar içermektedir (Zahavi, 2020: 89). Mekân; elaltındalığın -yani ilk karşılaşan şeylerin yanı başımızdaki şeylerin- bir özelliğidir. Sonrasında nesnelerle doldurulabilecek bir boş konteyner değildir (Zahavi, 2020: 89). Bu bağlamda Edward Relph ve Yi-Fu Tuan gibi coğrafyacıların yer kavramına yönelik analizleri, fenomenolojinin başlattığı bu mekân eleştirisi üzerinden yükselmektedir. Onlara göre bir fenomen olarak yer, algı dünyası ile birliktedir.

Edward Relph Place and Placelessness kitabında mekân ve yeri birbirinden ayırmaktadır:

Mekân amorf ve soyuttur ve tanımlanabilen ve analiz edilebilen bir anitete değildir. Yine de, mekânı hissediyor ya da biliyor ya da açıklıyoruz, ancak neredeyse her zaman mekân, yer kavramı ya da duyumla ilişkilidir. Genel olarak mekân yerler için bağlam sağlar ancak mekân, anlamını belirli yerlerden elde eder (Relph, 1976: 8).

Relph'e göreyer, doğrudan yaşam-dünyasının deneyimlendiği duyu-algısal alandır. Yerler, insani ve doğal düzenin kaynaşmasıdır (Relph, 1976: 140). Bu kaynaşmada yer (place), birikmiş bir bellek olarak yaşanan mekândır. Yersizlik (placelessness) ise, hem önemli yerlerin olmadığı bir ortamı hem de yerlerin önemini kabul etmeyen temel tutumu tanımlar (Relph, 1976: 143). Bu anlamiyla yersizlik, insan deneyimleri sonucunda kökleşmiş ve sembolleşmiş duyu-alanların tekdüze hale getirilmesi ve yaşam-dünyasının soyut kavramlara (geometrik-mekân) indirgenmesi sonucunda ortaya çıkmaktadır. 
Marc Augé da kimliklerin, ilişkilerin, değerlerin, sembolizmlerin anlamsızlaştığı ve ortadan kalktığı alanları yok-yer olarak tanımlamaktadır. Auge'ya göre, aşırı-modern ya da süpermodern bir dünyada her şeyin birbirine yakınlaşması, tarihin hızlanması ve küreselleşen dünyada bireyselleşmenin aşırılaşması, yok-yerlerde yaygınlaşarak somutlaşmaktadır. Bu yüzden "süper-modernitenin ürettiği yok-yerler antropolojik olmayan anlam mekânlarıdır" (Augé, 1995: 78). Augé için yer; kimliklerin, ilişkilerin ve belleğin üretildiği alanlardır.

Diğer yandan Edward Relph, Geographical Experiences and Being-In-The-World isimli makalesinde, Martin Heidegger'in çeşitli metinlerinden yirmi tane dipnota atıfta bulunmaktadır. Relph göre fenomenoloji gözlerimizin hemen önünde ama bir şekilde bizden gizlenmiş olan bir şeyi net bir şekilde görmemizi sağlayan bir düşünme şeklidir. "Heidegger'in önemi, bu 'bir şey' Varlık [Dasein] yani her şeyin var olduğu gerçeğini ortaya koymasıdır" (Relph, 1985: 6). Heidegger Varlık ve Zaman'da 'bir şey olarak Varlık' kavramını, Dasein ${ }^{14}$ ile ifade etmektedir. Dasein 'oradaki-varlık' anlamına gelmektedir: 'Oradaki-varlık varolan-şeydir ki, kendisini Varlığında anlayarak bu Varlığa doğru davranır" (Heidegger, 2004: 88). Heidegger'e göre Dasein, her zaman kendi varoluşunu anladığını ve kendi varoluşuna yöneldiğini ifade eder ${ }^{15}$. Çünkü insan, yapılı bir çevrede doğar ve doğduğu yerdeki el-altında-olan-şeyler (eşyalar, nesneler) ve var-olan-şeyler (doğal-fiziki yapı) ile varlığa gelmektedir. Bu yüzden yerler bir dizi tutum, değer, düşünce, inanç, anlam ve davranış eğilimi ile karakterize olan önemli bilişsel yapılardır (Proshansky vd., 2014: 77). Dolayısıyla hümanistlere göre mekân ve yere yönelik bir inceleme; saltgeometrik, bilimsel ve nesnel bir analiz ile açıklanamaz ancak insanların onu inşa etmelerine bağlı olarak tanımlanabilir.

Yu-Fi Tuan Geography, Phenomenology and The Study of Human Natura makalesinde fenomenolojiyi, fenomenlerin tanımlanması ve açıklığa kavuşturulması olarak tanımlamaktadır (Tuan, 1971: 181). Tuan makalenin temasını ise insanın aynasl olarak coğrafya şeklinde belirlemektedir. Ona göre “"ev', 'komşuluk', 'yolculuk' ve 'vahşi doğa' gibi kelimeler, gerçekliğin yönlerine bire bir karşılık gelen işaretler olmaktan çok uzaktır; ne demek istedikleri geçmiş deneyimlerin birikimini yansıtır" (Tuan, 1971: 190). Ona göre biz, kelime ve edinilmiş hazır gelenekler aracılığıyla eylemde bulunuyoruz ve algılıyoruz. Tuan'ın bu tanımlaması, Husserl'in 'yönelimsel' [intentio] kavramıyla doğrudan ilişkilidir.

Tuan, Space and Place kitabında, topophilia ve topophobia kavramlarını insanların belirli yerlerle ilişkilendirdikleri arzu ve korkuları ifade etmek için kullanarak mekânın şehvetli, estetik ve duygusal boyutlarına dikkat çekmektedir. Ona göre mekân kavramı yalnız başına karmaşık bir fikir kümesi için soyut bir terimdir. Farklı kültürlerden insanlar dünyalarını bölme, parçalarına değer atama ve onları ölçme biçimleri bakımından farkl111k gösterir (Tuan, 2001: 34). Bu yüzden 'bedensel deneyimler' ve 'insani ilişkiler' mekânın anlaşılmasında önemli rol oynamaktadır. Buna göre mekân, farklı insan öznelliklerinin 'dünya-içindeki-yerler' ile ilişkisinde açığa çıkmaktadır. Bu ilişkide mekân, "tanım ve anlam kazandıkça yere dönüşür" (Tuan, 2001: 136; Cresswell, 2004: 10). Buna göre yaşanılan deneyimler mekâna kök saldıkça 'yer'i meydana getirmektedir. Yerler kültürlerin, toplulukların ve insanların kendilerini köklendirdikleri ve kendilerini tanımladıkları alanlardır (Anderson, 2015: 51).

Tuan; ev, eşya, doğa, manzara ve diğer şeylerle yaşanılan dolayımsız karşılaşmaların yerin anlaşılmasındaki önemine dikkat çekmektedir (Tuan, 2001). Eşya ve coğrafi yapı üzerinden yerin tanımlanması, Gaston Bachelard'ın hayallerin fenomenolojisini imlemektedir. Bachelard Mekânın Poetikası kitabında, kendi 'hayal fenomenolojisi' görevini, yer-severlik [to-pophilie] soruşturması olarak açılar: "Soruşturmalarımıza, bu yönelim çerçevesinde, yer-severlik [to-pophilie] adı verilebilir. Bu soruşturmalar, sahip olduğumuz mekânların, rakip güçlere karşı savunduğumuz mekânların, sevdiğimiz mekânların insani değerini belirlemeyi amaçlıyor" (Bachelard, 2018: 28). Bachelard hayal gücü mekânlarının kökeninde bir 'yer-sevgisi' olduğunu ifade etmektedir. Bunu yaparken ise ev, eşya, çekmece, dolap, okyanus, kum, köşe gibi sözcüklerin şiirsel kullanımından yola çıkmaktadır. Bachelard'a göre "hayalgücünün kavradığı mekân, geometricinin ölçümüne ve düşüncesine teslim edilmiş kayıtsız bir mekân olarak kalamaz. Yaşanmış bir mekândır bu" (Bachelard, 2018: 28). Bu bağlamda yaşanılmış mekân, değerlerle yüklü bir 'yer'dir. Bu değerler, yere yönelik duygusal bir anlama ve insandaki yer aidiyetinin de temelini oluşturur.

Geçmişin güçlü etkilenmelerinden ortaya çıkan 'yer duygulanımları', yere yönelik bir aidiyetin sonucudur. $\mathrm{Bu}$ yüzden yerler "kim olduğumuzu ve yaşamımızın kültürüne ve coğrafyasında nerede oturduğumuzu anlamak için çok önemlidir" (Anderson, 2015: 51). Yerinden edildiğinde ya da başka bir yere gidildiğinde ortaya çıkan 'yabancı hissi'nin nedeni; yerin kimlik, bellek ve kültür ile harmanlanmış bir kompozisyona sahip olmasından ileri gelmektedir. Roland Barthes'in ifadesiyle: “[...] bir ülkeyi, bir memleketi 'okumak' önce onu bedene ve belleğe göre, bedenin belleğine göre algılamaktır” (Barthes, 1999: 18). Dolayısıyla yer duygusu, yer ile kurulan bireysel bir 
ilişki olmakla birlikte aynı zamanda paylaşılan anlamları da içermektedir. Bu yüzden yer hem maddi hem de soyut olmak üzere ikili bir özelliği yansıtmaktadır. Cresswell'e göre yer ve anlam kombinasyonu, 'deneyim' temelli maddi bir olgu olarak ortaya çıkmaktadır: "Yerler, mekânın belirli bir bölümünü işgal eden ve kendilerine bağlı bir takım anlamlara sahip olan maddi şeylerin belirli takımyıldızlarıdır" (Cresswell, 2013: 113). Cresswell aşağıda verdiği örnekte yerin maddi anlamını vurgulasa da örnekte yerin soyut anlamı da ortaya çıkmaktadır: "Favori bir sandalyenin bile belirli bir yeri (belki şöminenin önü), fiziksel bir yapısı (yıpranmış kolçaklar, sallanan bacaklar) ve anlamları (belki de çocukken size hikâye okurken babanızın oturduğu yer) vardır" (Cresswell, 2013: 113). Babanın oturduğu koltuğun maddi deneyimi anlamı ortaya çıkarmakla birlikte, babanın koltuğuna benzer bir koltukla karşılaşıldığında 'babanın koltuğunu' anımsama, ilk 'fiziki koltuk' deneyimini soyutlamaktadır. Bu ikili işlev, yerin statik ve sabitliğine karşın onun dinamizmini ortaya koymaktadır. Bu bağlamda yere özgü anlamlar, bellek aracılığıyla 'hareket' halindedir. Çünkü her insanın günlük varlığını tanımlayan fiziksel ortamın çeşitliliği ve karmaşıklığı ile anılar, fikirler, duygular, tutumlar, değerler, tercihler, anlamlar ve davranış ve deneyimlerin hareketinde 'çevresel geçmiş' (bellek) vardır (Proshansky vd., 2014: 77). Dolayısıyla yerin soyut ve somut özelliğinin sonucu olarak 'duyu hisleri', hayatın ritmi içerisinde insanlarda yere duyulan farklı aidiyet biçimleri oluşmaktadır (Low and Altman, 1992; Seamon, 1985). Bu aidiyet, çevre ve 'yer kimliği' ile birlikte 'bireysel kimlik'in de ön koşulunu oluşturmaktadır.

Genel olarak, insanların yer deneyimi sonucunda üretmiş olduğu fikirler, duygular ve gündelik yaşam ilişkilerinde üretilen anlamlar; kültürel coğrafi çalışmalar için önemli katkılar sağlamaktadır. Trevor J. Barnes ve James S. Duncan, yerin bireysel ve toplumsal ilişkiler bağlamında ürettiği anlamları; 'metin', 'gösterge' ve 'sembol' gibi kavramlarla coğrafi manzaranın nasıl şekillendiğini tartışırlar. Barnes ve Duncan'a göre kültürel coğrafi manzara; metinler, söylemler veya metaforlar aracılı̆̆ıyla işlenmektedir (Barnes and Duncan, 2006: 11). Buna göre coğrafi manzaranın yani şehirsel peyzajın yazılması belirli kültürel ve toplumsal temsiller içermektedir.

İnsan ve yer ilişkisinde yeri yapılandıran anlam sistemleri, farklı kültür temsilleri aracılığıyla coğrafi manzarayı dönüştürmektedir. Bu anlamıyla coğrafya, üzerine 'yazıların' (deneyim) yazıldığı bir 'metin'dir. Buradaki 'metin' kavramı eleştirel bir metodolojiye de vurgu yapmaktadır. Bu yüzden coğrafi manzaranın metin aracılığıyla analizi; belli ideolojik söylemlerin coğrafi manzaraya nasıl yansıtıldı̆̆ ve bunun gündelik ilişkilerdeki dönüştürücü işlevini de ortaya çıkarmaktadır. (Duncan and Duncan, 2006a: 18). Yine Denis Cosgrove, coğrafyacıları eleştirerek yerin sembolizmle yüklü anlamına dikkat çekmektedir:

Coğrafya alanı, insan manzarasında gömülü olan anlamın çoğunu gözden kaçırıyor ve onu demografik ve ekonomik güçlerin kişisel olmayan bir ifadesine indirgeme eğiliminde. Bir romanı, şiiri, filmi veya resmi incelerken kullandığımız yorumlama becerilerinin bazılarını insan manzarasına uygulama, onu birçok anlam katmanından oluşan kasıtlı bir insan ifadesi olarak işleme fikri bize oldukça yabancıdır (Cosgrove, 1989: 119).

Hümanist coğrafi anlayışın yer yaklaşımına yönelik farklı eleştirel yaklaşımlar ortaya konulmuştur. Özellikle David Harvey, Neil Smith ve Edward Soja gibi Marksistler'e göre hümanistler, iktidarın sistematik ve yapısal düzenlemelerini; baskı, sömürü ve tahakküm ilişkilerini göz arzdı etmektedirler. Adı geçen coğrafyacılar, Henri Lefebvre'nin Marksist mekân okumasindan hareket etmektedirler. Marksistlere göre, mekân ne olayların gerçekleşmesi için bir zemindir ne de evrensel bir kategoridir.

Henri Lefebvre Mekânın Üretimi kitabında mekânı, siyasal stratejiler bakımından 'üretilen' ve 'yeniden üretilen' bir yer olarak açıklamaktadır. Lefebvre fenomenoloji ve mutlak mekân düşüncesinin göz ardı ettiği mekânın siyasal ve toplumsal boyutunu 'üretim' kavramı üzerinden analizinin merkezine koymaktadır (Lefebvre, 2014: 99/210/304). Lefebvre, fenomenolojinin yanında astronomi ve matematiğin 'geometrik boş bir mekân' olarak ele aldığı 'mekân bilimi' ile Descartes'ın Kartezyen mekânı ve Kant'ın a priori mekân yaklaşımını 'mekân felsefesi' bağlamında eleştirmektedir. Lefebvre buradaki eleştirisini toplumsal mekân kavramıyla ortaya koymaktadır:

Toplumsal mekân, (filozofların ve matematikçilerin tanımladığı) zihinsel mekânla keza, (pratik-duyumsal olanla ve 'doğa' algısıyla tanımlanan) fiziksel mekânla artık örtüşmediğinden, kendi özgünlüğünü ortaya koyar. Bu toplumsal mekânı, şeyler dizisinden, (hissedilir) olgular toplamından, keza bir paket gibi içine çeşitli maddeler doldurulmuş bir boşluktan ibaret olmadığını; fenomenlere, şeylere, fiziksel maddiliğe dayatılmış bir 'biçime' indirgenemeyeceğini göstermek gerekecektir (Lefebvre, 2014: 57).

Lefebvre'ye göre yer; bireysel deneyimler yoluyla fenomenolojik olarak incelenebilse de, o anlamını maddi ve 
sosyal formlardaki mekânsal üretimin politik ve ekonomik güçlerinden ve sınıf ilişkilerinden almaktadır. $\mathrm{Bu}$ yüzden toplumsal mekân; insanları, uygulamaları, dilleri ve temsilleri içeren ağlar aracılığıyla yapılandırılmakta ve kapitalist üretim ilişkileri çerçevesinde yeniden üretilmektedir (algılanan, tasarlanan ve yaşanan).

Lefebvre'ye göre tarihsel süreçte üretim ilişkiler çerçevesinde şekillenen dört mekân türü vardır: Mutlak mekân, soyut mekân, çeliş̧kili mekân ve diferansiyel mekân. Lefebvre 'mutlak mekân'1, sermayenin sömürmediği 'tarihsel yerler' olarak tanımlamaktadır: "Mutlak mekânın beşiği, kökeni (eğer bu terimi kullanmak istersek) tarımcı-pastoral bir mekân parçasıdır, yani köylülerin, göçebe ve yarı göçebe çobanlarının adlandırıldığı ve çalıştığı yer kümesidir" (Lefebvre, 2014: 45). "Soyut mekân (...) şiddetin ve savaşın ürünü olarak siyasaldır ve bir devlet tarafindan kurulmuştur, dolayısıyla kurumsaldır” (Lefebvre, 2014: 92). 'Soyut mekân', üretim ve yeniden üretimin gerçekleştiği siyasal mekândır. Burada mekân siyasal bir strateji dâhilinde üretilmektedir. 'Çelişkili mekân' ise soyut mekândan kaynaklı çelişkilerin mekânıdır. Burada mekân parçalama, bölme ve düzenleme olarak yeniden üretilmektedir. Çelişkili mekân, mekânsal planlamanın etkin gözüdür (Lefebvre, 2014: 353). Son olarak 'diferansiyel mekân', farklı yerlerin bir birleşiminden oluşan mekândır. Lefebvre'ye göre mekânın (modern) mutlak tasavvuru ve temsil edilişi, soyut mekân üretimini güçlendirmektedir.

Yer ve fenomenoloji ilişkisinde duyu-hislerin yerlerle olan özdeşliği, bireysel kimlik ve bellek konusunda önemli sonuçlar ortaya koymaktadır. Fakat yerin kimlik ve bellek ile olan ilişkisi 'soyut' ve 'çelişkili mekân' bağlamında ele alındığında; yaşanılan yere toplumsal, ekonomik ve siyasal temsil edişler doğrudan dâhil olmaktadır. Bu yüzden yere yönelik hümanist atıflar yerin toplumsal, ekonomik ve politik işleyişini göz aradı etmektedir (Lefebvre, 2014). Dolayisiyla Lefebvre hem mekânı 'mutlak mekân' düşüncesinden kurtarmakta hem de yerin hümanist bir açıklamasını eleştirerek, Agnew'in de vurguladığı gibi (2005: 90), mekân ve yeri ilişkisel bir perspektife oturtmaktadır.

Marksist düşünür Harvey, her şeyden önce mekânın 'boş bir kap olmadığı', toplumsal pratikler ve süreçler tarafindan üretilen, değiştirilen ve yeniden dönüştürülen bir yer olduğuna dikkat çekmektedir. Harvey'e göre toplumsal süreçler ile mekânsal biçimler birbiriyle ilişkilidir. Burada mekânsal biçimler, içinde toplumsal süreçlerin oluştuğu cansız nesneler olarak değil, toplumsal süreçleri bu süreçlerin mekânsal olmasıyla aynı tarzda 'içeren' şeyler olarak görülmelidir (Harvey, 2009: 16). Bu bağlamda mekân, sosyal yaşamın hem sebebi hem de sonucudur yani 'ilişkiseldir'; hem üreten hem de üretilendir.

Harvey, mekân ve yer ilişkisinde yer'i insan, kültür ve gelenek de dâhil yapılı bir mevkii ve onu diğer mevkilerden ayıran, kendine has özgüllüğü ile açıklamaktadır. Harvey’e göre bu farklı yerler, kapitalist sistem tarafindan farklı üretim tarzları bağlamından kendi özgünlükleri korunarak bir araya getirilmektedir. Tüm bu bir araya getirme işlemleri, mekânın mutlak olduğu ön varsayımından hareketle yapılmaktadır. Bu yüzden Harvey; kültürel uygulamaların, temsillerin ve hayal gücünün iç içe geçtiği, eleştirel bir mekânsallığa dikkat çekmektedir. Çünkü Harvey mekânı genellikle emredilen ve kontrol edilen yerler olarak görmektedir. Bu çerçevede soyut mekân, mekânsal müdahale ve kontrollerle somut mekânı yani yeri ele geçirme stratejisine dayanmaktadır.

Doreen Massey; Harvey ve Lefebvre'nin aksine mekânın üretimini yalnızca sermaye akımları, birikimleri, hareketliliği ve sömürüsü olarak düşünmez; daha ziyade mekânı 'gevşek uçlar ve eksik bağlantılar' olarak tanımlamaktadır (Massey, 2008: 12; Massey, 1999: 2). Massey mekânı, mekân-zamandaki eşsiz kavşaklarda değişen derecelerdeki hikayelerin bir araya getirilmesi olarak görmektedir. Bu nedenle yerler; daha iyi sinırları olan 'kaplar', haritadaki konumlar, yapılar değil, 'mekân-zamansal' olaylardır (Massey, 2008: 130). Zamanmekânsal olaylar akış içerisinde düşünüldüğünde, bütünsel olarak tanımlanamaz ve öngörülemez: "Mekân hiçbir zaman tüm bağlantıların kurulduğu ve her yerin zaten başka her yerle bağlantılı olduğu o tamamlanmış eşzamanlılık olamaz" (Massey, 1999: 2). Bu yüzden mekân, mekân-zamandaki eşsiz (farklı) kavşaklarda meydana gelen aktivitelerdir. Buradaki aktiviteler farklı 'yer'lerde meydana gelen anti-özcü oluşlardır. Buradan hareketle Massey, mekân ve yer ayrımını reddettiğini ifade eder: "Peki ya yer (anlamlı, yaşanmış ve gündelik) ve mekân (ne? dışarısı? soyut? anlamsız) arasındaki çok çekici görünen bu ayrımı reddedersek ne olur?" (Massey, 2008: 6). Bu bağlamda Massey düşüncesinde mekân ve yer ilişkisel bir düzleme sahiptir:

Yerleri etraflarında sınırları olan alanlar olarak düşünmek yerine, sosyal ilişkiler ve anlayış ağlarında eklemlenmiş anlar olarak düşünülebilir, ancak bu ilişkilerin, deneyimlerin ve anlayışların büyük bir kısmının o an için, ister bir sokak, ister bölge, hatta bir kıta olsun bizden çok daha büyük bir ölçekte inşa edildiği yerler yerin kendisi olarak tanımlanır. Ve bu da, küresel ve yerel olanı olumlu bir şekilde bütünleştiren, daha geniş dünyayla bağlarının bilincini içeren dışa dönük bir yer hissine izin verir (Massey, 2001: 154). 
$\mathrm{Bu}$ yüzden Massey; merkezi olmayan küresel bir yer duygusuna dikkat çekerek mekânın evrenselliği ile yerin tikelliğini birleştirir yani evrensel - tikel karşıtllı̆ını aşmaya çalışmaktadır. Bunun için de küresel ağ bağlantıları kavramıyla yeri, içinde olanlarla değil dünyanın diğer yerlerindeki farklı bağlantı çizgileriyle düşünmektedir.

\section{SONUÇ}

Gündelik sözlüklerde mekân ve yer kimi zaman birbiri yerine açıklansa da temelde, mutlak mekân düşüncesinden hareketle formüle edilmiştir. Bütün gündelik sözlüklerde yer, mutlak mekânda bir konum olarak tanımlanmıştır. Disiplin sözlüklerinde de (sosyoloji hariç) mekân ve yer net bir şekilde birbirinden ayrı olarak düşünülmekte ve yer, mekânda bir konum olarak açıklanmaktadır. Burada mekân soyut ve matematiksel bir düzleme ilişkin iken; yer, yeryüzü ile ilişskili bir konum olarak tanımlanmıştır. Ayrıca siyaset sözlüklerinde mekân ve yer tanımlanmamış olsa da, mekânsal işleyiş mutlak mekân düşüncesine dayanmaktadır.

Bu çalışmada yerin hem somut hem de soyut olmak üzere iki farklı anlamına ulaşılmıştır ve bu ikili anlam mekân ve yerin ilişkisel boyutunu ortaya koymaktadır. Yer bir taraftan maddifiziki bir deneyime bağlanırken, diğer yandan maddi-fiziki özelliğinden dolayı soyutlanmaktadır. Fakat bu soyutlamanın kendisi de fiziki-maddi bir özelliği ön varsaymaktadır. Örneğin ilk defa gittiğim bir evde, şunu söyleyebilirim: kendi evimdeymiş gibi hissediyorum. Bir önceki fiziki-maddi ev deneyimi, ikinci fiziki-maddi ev deneyimi üzerinden bendeki yer hissini soyutlamaktadır. Yerin hem soyut hem de somut olma özelliği, Massey'in 'evrensel (mekân)-tikel (yer)' arasındaki kesişim ilişkisini olumlamaktadır. Çünkü bir yer, yalnızca bir yer değildir. Yani bir yere yönelik farklı deneyim biçimleri ve bu deneyim biçimlerinin yarattığı farklı anlamlar; yer değiştirmelere rağmen bellekteki sürekliliğini, hareketliliğini ve dinamikliğini korumaktadır. Bu durumda mekân ve yer, içe içe geçen olgular olarak ortaya çıkarmaktadır.

Mutlak mekân düşüncesi, yerle yaşanan farklı deneyim biçimlerinin yaratmış olduğu farklı anlam sistemlerini homojenleştiren siyasal bir müdahale biçimidir. Mekân, Foucaultcu anlamda, içindeki yerlerin normalleştirmesinde ve homojenleştirilmesinde kullanılan bir stratejisidir. Bu strateji düşünce tarihinde mekâna yönelik açıklama ve tanımlamalarda görülen bir olgudur. Çünkü tarihsel süreçte mekân, bir koordinat sisteminde sanki gözlemci veya kontrolör onu oluşturan yerlerin dışındaymış ve aşağıya bakıyormuş gibi soyutlanmaktadır. $\mathrm{Bu}$ soyutlamada insan mekânda hem özne (kontrol eden) hem de nesne (kontrol edilen) durumundadır. Dolayısıyla yer, bu koordinatlar düzleminde 'homojen bir nokta' olarak hesaplanmaktadır. Fakat nokta olarak yeri hesaplayan kişi, bizatihi öznel yer deneyiminden hareketle bunu yapmaktadır. Bu yüzden yerleri mekânsal hesaplamalarla düzenlemeye çalışan dışsal göz, bu düzenlemeyi kendi öznel yer deneyiminden hareketle evrenselleştirmektedir. $\mathrm{Bu}$ bağlamda mekân "yukarından aşağıya"; yer, 'aşağıdan yukarıya' doğru işleyen ilişkisel bir süreçtir.

Mutlak mekân perspektifinin, politikaların coğrafyalara uygulanmasında kullanılan bir yöntem olduğunu görmekteyiz. Bu politikalar aynı zamanda mekân ve yer arasındaki ilişkinin en somut örneği olarak görülebilir. Özellikle mekân ve yer ilişkisi merkezileşmenin yoğunlaştığı ülkelerdeki kamusal politikaların oluşturulması sürecinde ortaya çıkmaktadır. Kamusal politikaların üretiminde mekân, çoğunlukla, mutlak olarak görülür ve bütün ülke sathına homojen politikaların uygulanması deklare edilir. Bu yüzden farklı yer/el özellikler göz ardı edilir ve mekân üzerinde yaşayanlar yalnızca nicel bir nüfus sayımı ilkesi olarak düşünülür.

\section{NOTLAR}

1 https://sozluk.gov.tr/ (Erişim Tarihi: 01.02.2021)

2 https://sozluk.gov.tr/ (Erişim Tarihi: 01.02.2021)

3 https://www.oxfordlearnersdictionaries.com/definition/english/ space_1?q=space (Erişim Tarihi: 01.02.2021)

4 https://www.oxfordlearnersdictionaries.com/definition/english/ place_1?q=place (Erişim Tarihi: 01.02.2021)

5 https://www.duden.de/suchen/dudenonline/der\%20Raum (Erişim Tarihi: 01.02.2021)

6 https://www.verbformen.com/declension/nouns/Ort.htm (Erişim Tarihi: 02.02.2021).

7 https://www.larousse.fr/dictionnaires/francais/espace/31013 (Erişim Tarihi: 02.02.2021)

8 https://www.larousse.fr/dictionnaires/francais/place/61263?q $=$ place $\# 60860$

https://www.larousse.fr/dictionnaires/francais/lieu/47076?q=lieu\# 47003 (Erişim Tarihi: 02.02.2021)

9 https://www.dizionario-italiano.it/dizionario-italiano.php?parola= spazio

https://www.dizionario-italiano.it/dizionario-italiano.php?parola= Luogo https://www.dizionario-italiano.it/dizionario-italiano.php?parola= posto (Erişim Tarihi: 01.02.2021)

10 Uzam: "Zaman içinde varolup, fiziki mekânda yer işgal etme. Elle tutulabilir, değiştirilebilir, bölünebilir, hareket ettirilebilir olup, 
şekli ve büyüklüğü olan maddenin yer kaplama özelliği olarak açıklanmaktadır" (Cevizci, 1999: 875; Hançerlioğlu, 2006: 433).

11 Uzay: Bedia Akarsu Felsefe Terimleri Sözlüğü’nde uzay teriminin İngilizce karşılığı olarak space kavramını kullanmaktadır (Akarsu, 1975: 175). TDK Sözlüğü'nde ise uzay: 1- bütün varlıkların içinde bulunduğu sonsuz boşluk, feza, mekân; 2- bütün gökcisimlerinin içinde bulunduğu sınırsız boşluk (https://sozluk.gov.tr/ Erişim Tarihi: 01.02.2020). Coğrafya Sözlüğü'nde ise uzay [spatial], bir manzara veya yüzey boyunca dağılım veya konum olarak açıklanmaktadır (Mahyew, 2003: 563).

12 İncelenen sözlükler: Edt: Raynaud, P., Rials, S. (2003), Siyaset Felsefesi Sözlüğü, çev: İsmail Yerguz vd., İstanbul - İletişim Yayınları; Heywood, A. (2012), Siyasetin Temel Kavramları, çev: Hayrettin Özler, Ankara - Adres Yayınları; Scruton, R. (2007), Dictionary of Political Thought, New York - Palgrave Macmillan; Bealey, F. (1999), Dictionary of Political Science: A User's Guide to Its Terms, Oxford - Oxford University Press; Collin, P. H. (2004), Dictionary of Politics and Government, London - Bloomsbury; Robertson, D. (2004), Dictionary of Politics, London \& New York, Routledge.

13 Ponty için beden-özne, kişinin mekânı algılaması ve duyumsamasıdır. Mekândaki ilksel karşılaşmayı algılama biçimidir. Ponty'nin beden-özne kavramsallaştırması aynı zamanda Descartes'tan süregelen beden-zihin ayrımının da bir eleştirisidir.

14 Heidegger Dasein'1, dünya-içinde-olma [In-der-Welt-sein] olgusu ile açıklamakta ve dünya-içinde-olma 'işte ben bu varolanım' demektir. Bu varolma biçimi, dünyadaki diğer fenomenlerle birlikte var olmadır. Heidegger'e göre, Dasein zaten dünyanın içinde konumlanmış bir şekilde dünyayı tecrübe etmektedir. Bu tecrübe, ikamet etmek [dwelling] kavramı çerçevesinde irdelemektedir. İkamet-etme, hem el-altında-olan-şeylerle hem de var-olan-şeyler ile birlikte dünyada-olmaktır [Mitsein] (Heidegger, 2004: 154/170). $\mathrm{Bu}$ yüzden dünya, her nasılsa öyle olan varolanlarla birlikte karşılaştığımız yerdir. Bu karşılaşma dünyadaki şeylere dâhil olmayı içermektedir.

15 Heidegger Dasein'a yönelik analizini fenomenolojik bir yöntemle açıklamaktadır. Ona göre fenomenolojik gerçeklik Varlığın açığa serilmişliğidir (Heidegger, 2004: 68). Fenomenoloji Dasein'ın varoluşsal yapısını ortaya seren bir yöntemdir.

Hakem Değerlendirmesi: Dış bağımsız.

Yazar Katkıları: Çalışma Konsepti/Tasarım- S.B., S.B.; Veri Toplama- S.B., S.B.; Veri Analizi/Yorumlama- S.B.; Yazı Taslağı- S.B., S.B.; İçeriğin Eleștirel İncelemesi- S.B.; Son Onay ve Sorumluluk- S.B., S.B

Çıkar Çatışması: Yazarlar çıkar çatışması bildirmemiştir.

Finansal Destek: Yazarlar bu çalışma için finansal destek almadığını beyan etmiştir.

Peer-review: Externally peer-reviewed.

Author Contributions: Çalışma Konsepti/Tasarım- S.B., S.B.; Veri Toplama- S.B., S.B.; Veri Analizi/Yorumlama- S.B.; Yazı Taslağı- S.B., S.B.; İçeriğin Eleştirel İncelemesi- S.B.; Son Onay ve Sorumluluk- S.B., S.B.

Conflict of Interest: The authors have no conflict of interest to declare.

Grant Support: The authors declared that this study has received no financial support.

\section{KAYNAKÇA/REFERENCES}

Agnew, J. (2005). Space: Place. In, Cloke, P., Johnston, R. (Ed). Spaces of Geographical Thought: Deconstructing Human Geography's Binaries (pp: 81-96). New Delhi: SAGE Publications.

Akarsu, B. (1975). Felsefe Terimleri Sözlüğü. Ankara: Türk Dil Kurumu Yayınlar1.

Althusser, L. (2005). Montesquieu: Siyaset ve Tarih. (A. Tümertekin, Çev,), İstanbul: İthaki Yayınları.

Anderson, J. (2015). Understanding Cultural Geography: Place and Traces. New York: Routledge.

Aristoteles. (2014). Politika. (M. Tunçay, Çev.). İstanbul: Kabalcı Yayınlar1.

Augé, M. (1995). Non-Places: Introduction to An Antropology of Supermodernity. Trans: John Howe, London: VERSO.

Bachelard, G. (2018). Mekânın Poetikası. (A. Tümertekin, Çev.), İstanbul: İthaki Yayınları.

Baker, S. F. (2003). Matematik Felsefesi. (Y. Dursun, Çev.), Ankara: İmge Yayınları.

Barnes, T. J., \& Duncan, J. S. (2006). Introduction: Writing Worlds. In, T. J. Barnes and J. S. Duncan (Ed). Writing Worlds (pp:1-17). New York: Routledge.

Barthes, R. (1999). Ara Olaylar. (S. Rıfat, Çev.), İstanbul: Kaf Yayınc1lık.

Berlinski, D. (2013). The King of Infinite Space: Euclid and His Elements. New York: Basic Book.

Bozdoğan, S. (2019). Mekân ve Siyaset İlişkisi: Aristoteles'ten İbn Haldun'a Teorik Bir Inceleme. (Doktora Semineri). Harran Üniversitesi. Sosyal Bilimler Enstitüsü. Şanlıurfa.

Bunge, W. (1960). Theoretical Geography. Lund: Royal University Press.

Bunge, W. (1979). Fred K. Schaefer and The Science of Geography. Annals of The Association of American Geographers, 69(1), 128132.

Bunge, W. (1979a). Perspective and Theoretical Geography. Annals of The Association of American Geographers, 69(1), 169-174.

Burton, I. (1963). The Quantitative Revolution and Theoretical Geography. Canadian Geographer, VII(4), 151-162.

Certeau, M. D. (2008). Gündelik Yaşamın Keşfi I. (L. A. Özcan, Çev.), Ankara: Dost Kitabevi.

Cevizci, A. (1999). Felsefe Sözlüğü. İstanbul: Paradigma Yayınları. Comte, A. (2015). Pozitivist Felsefe Dersleri ve Pozitivist Anlaylş Üzerine Konuşma. (E. Ataçay, Çev.). Ankara: Bilgesu Yayıncılık.

Cosgrove, D. (1989). Geography is Everywhere: Culture and Symbolism in Human Landscapes. In, D. Gregory and R. Walford (Ed). Horizons in Human Geography (pp: 118-135). London: Macmillan Press.

Crampton, J. W., \& Elden, S. (2007). Space, Knowledge and Power: Foucault and Geography. Cornwall: ASHGATE.

Crampton, J. W., \& Elden, S. (2006). Space, Politics, Calculation: An Introduction. Social and Cultural Geography, 7(5), 681-685. 
Cresswell, T. (2013). Geographic Thought: A Critical Introduction. New Jersey: Wiley-Blackwell.

Cresswell, T. (2004). Place: A Short Introduction. New Jersey: WileyBalckwell.

Christaller, W. (1966). Central Places in Southern Germany. London: Prentice Hall.

Descartes, R. (2015). Meditasyonlar: Metafizik Üzerine Düşünceler. (Ç. Dürüşken, Çev.), İstanbul: Alfa Yayınları.

Descartes, R. (2007). Felsefenin Illkeleri. (M. Akın, Çev.), İstanbul: Say Yayınları.

Descartes, R. (1989). Aklın İdaresi İçin Kurallar. (M. Karasan, Çev.), Çev: Ankara: Milli Eğitim Bakanlığı Yayınları.

Descartes, R. (1988). Felsefenin Ilkeleri. (M. Karasan, Çev.), Ankara: Milli Eğitim Bakanlığı Yayınları.

Dictionary of Mathematics (2003). United States: McGraw Hill.

Doğanay, H. (2017). Coğrafya Bilim Alanları Sözlüğü. (Namık Tanfer Altaş, Edt.), Genişletilmiş 2. Basım, Ankara: Pegem Akademi.

Duncan, J. S., \& Duncan, H. G. (2006). Ideology and Bliss: Roland Barthes and The Secret Histories of Landscape. In, T. J. Barnes and J. S. Duncan (Ed). Writing Worlds (pp:18-37). New York: Routledge

Elden, S. (2007). Governmentality, Calculation, Territory. Environment and Planning D: Society and Space, 25, 562-580.

Foucault, M. (2016). Güvenlik, Toprak, Nüfus. (F. Taylan, Çev.). İstanbul: İstanbul Bilgi Üniversitesi Yayınları.

Foucault, M. (2015). Toplumu Savunmak Gerekir. (Ş. Aktaş, Çev). İstanbul: Yapı Kredi Yayınları.

Foucault, M. (2014). Özne ve İktidar. (I. Ergüden ve O. Akınhay, Çev.), İstanbul: Ayrıntı Yayınları.

Gauch, H. G. Jr. (2016). Bilimsel Yöntem. (İ. Yıldız, Çev.), Ankara: Dipnot Yayınlar1.

Gleeson, B. (1996). A Geography for Disabled People. Transactions of The Institute of British Geographers, 23, 387-96.

Grange, J. (1985). Place, Body and Stuation. In, Seamon, D. Murgerauer, R. (Ed). Dwellin, Place and Environment: Towards a Phenomenology of Person and World (pp: 71-84). Dodrecht: Martinus Nijhoff Publishers.

Gregory, D. (2009). Space. In, Gredory, D. vd. (Ed). The Dictionary of Human Geography (pp: 707-710). New Jersey: Wiley - Blackwell.

Gregory, D. (1978). Ideology, Science and Human Geography. London: Hutchinson.

Golledge, R. G. (2008). Behavioral Geography and The Theoretical/ Quantitative Revolution. Geographical Analysis, 40, 239-257.

Haggett, P. (1969). Locational Analysis in Human Geography. London: Edward Arnold.

Hançerlioğlu, O. (2006). Felsefe Sözlüğü. İstanbul: Remzi Kitabevi.

Hançerlioğlu, O. (1985). Felsefe Ansiklopedisi: Kavramlar, Akımlar (3. ve 7. Cilt). İstanbul: Remzi Kitabevi.

Harvey, D. (2009). Sosyal Adalet ve Şehir. (M. Moralı, Çev.), Çev: İstanbul: Metis Yayınları.

Hayden, D. (2014). Urban Landscape History: The Sense of Place and Politics of Space (1995). In Gieseking, J. J. vd. (Ed), The People, Place and Space Reader (pp:82-86). New York: Routledge.
Heidegger, M. (2004). Varlık ve Zaman. (A. Yardımlı, Çev.), İstanbul: İdea Yayınları.

Henderson, G. (2009). Place. In Gregory, D. vd., The Dictionary of Human Geography (pp:539-541). New Jersey: Wiley-Blackwell

Hubbard, P., Kitchen, R. (2011). Introduction: Why Key Thinkers?. In, Hubbard, P., Kitchen, R. (Ed). Key Thinkers on Space and Place (pp: 1-17). New York: SAGE Publising.

Hubbard, P. (2005). Space/Place. In, Sibley S vd. (Ed). Cultural Geography: A Critical Dictionary of Key Concepts (pp41-48). London: I. B. Tauri Press.

Husserl, E. (2010). Fenomenoloji Üzerine Beş Ders. (H. Tepe, Çev.), İstanbul: Bilgesu Yayınc1lık.

Husserl, E. (1970). The Crisis of European Sciences and Transcendental Phenomenology: An Introduction to Phenomenological Philosophy. Trans: David Carr, Evanston: Northwestern University Press.

https://www.dizionario-italiano.it/dizionario-italiano. php?parola=spazio (Erişim Tarihi: 01.02.2021)

https://www.dizionario-italiano.it/dizionario-italiano. php?parola=Luogo (Erişim Tarihi: 01.02.2021)

https://www.dizionario-italiano.it/dizionario-italiano.php?parola=posto (Erişim Tarihi: 01.02.2021)

https://www.duden.de/suchen/dudenonline/das\%20Erdreich (Erişim Tarihi: 01.02.2021)

https://www.duden.de/suchen/dudenonline/der\%20Raum

(Erișim

Tarihi: 01.02.2021)

https://www.larousse.fr/dictionnaires/francais/espace/31013 (Erişim Tarihi: 01.02.2020)

ht tps://www. larousse.fr/dictionnaires/francais / place/61263?q=place\#60860 (Erişim Tarihi: 01.02.2021)

https://www.larousse.fr/dictionnaires/francais/ lieu/47076?q=lieu\#47003 (Erişim Tarihi: 01.02.2021)

https:/www.oxfordlearnersdictionaries.com/definition/english/ place_1?q=place (Erişim Tarihi: 01.02.2021)

https://www.oxfordlearnersdictionaries.com/definition/english/ space_1?q=space (Erişim Tarihi: 01.02.2021)

https://sozluk.gov.tr/ (Erişim Tarihi: 01.02.2021)

https://www.verbformen.com/declension/nouns/Ort.htm (Erişim Tarihi: 02.02.2021)

Isin, E. (2006). Space. In Turner, B. (Ed), The Cambridge Dictionary of Sociology. UK: Cambridge University Press.

İzbırak, R. (1976). Coğrafya Terimleri Sözlüğü. İstanbul: İkbal Matbaacilik.

Kant, I. (1993). Arı Usun Eleştirisi. (A. Yardımlı, Çev.), İstanbul: İdea Yayınları.

King, L. J. (2021). Central Place Theory. West Virginia University, The Web Book of Regional Science, Regional Research Institute. Virginia.

Koç, Y. (1984). Determinizm ve Mekân. İstanbul: Boğaziçi Üniversitesi Yayınları.

Lefebvre, H. (2014). Mekânın Üretimi. (I. Ergüden, Çev.), Işık Ergüden, İstanbul: Sel Yayıncıl1k. 
Ley, D. (1980). Geography without Man: A Humanistic Critique. Oxford School Geography Researh Paper, No:24.

Lin, M. (2015). Leibniz on the Modal Status of Absolute Space and Time. NOUS, 1-18.

Low, S. M., Altman, I. (1992). Place Attachment: A Conceptual Inquiry. In, Irvin Altman and Setha M. Low (Ed.), Place Attachment (pp:112), New York: Plenum Press.

Massey, D. (2008). For Space. London: SAGE.

Massey, D. (2001). Space, Place and Gender. Minneapolis: University Minnesota Press.

Massey, D. (1999). Philosophy and Politics of Spatiality: Some Considerations. Geographische Zeitschrift, 87, 1-12.

Maudlin, T. (2012). Philosophy of Physics: Space and Time. New Jersey: Princeton University Press.

Mayhew, S. (2003). Oxford Dictionary of Geography. Oxford: Oxford University Press.

Montesquieu. (2017). Kanunların Ruhu Üzerine. (B. Günen, Çev.). İstanbul: İş Bankası Kültür Yayınları.

Naushoğlu, R., Bingöl, G., Gür, H., İnan, D., ve Ünal, N. (1989). Fizik Terimleri Sözlüğ̈̈. Ankara: Türk Dil Kurumu Yayınları.

Oxford Dictionary of Physics. (2003). Oxford: Oxford University Press.

Özgüç, N. ve Tümertekin, E. (2000). Coğrafya: Geçmiş, Kavramlar, Coğrafyacılar. İstanbul: Çantay Kitabevi.

Pickles, J. (2011). Uzamların Tarihi: Haritacılık Mantığl ve Coğrafi Olarak Kodlanmış Dünya. (K. Işık, ÇEv.), İstanbul: Yapı Kredi Yayınları.

Pickles, J. (1987). Geography and Humanism. Norwich: Geo Books.

Pitts, F. R. (1972). Spatial Organization: The Geographer's View of the World by Ronald Abler; John S. Adams; Peter Gould. Geographical Review, 62(3), 431-432.

Ponty, M. M. (2016). Algının Fenomenolojisi. (E. Sarıkartal ve E. Hacımuratoğlu, Çev.), İstanbul: İthaki Yayınları.

Ponty, M. M. (2010). Algılanan Dünya. (Ö. Aygün, Çev.), İstanbul: Metis Yayınları.

Proshansky, H. M., Fabian, A. K., \& Kaminof, R. (2014). Place-Identity: Physical World Socialization of The Self (1983). In, Gieseking, J. J. vd. (Ed). The People, Place and Space Reader (pp: 77-82). New York: Routledge.
Relph, E. (1976). Place and Placelessness. New Delhi: Pion Limited. Relph, E. (1985). Geographical Experiences and Being-In-The-World: The Phenomenılogy Origins of Geography. In, Seamon, D. Murgerauer, R. (Ed). Dwellin, Place and Environment: Towards a Phenomenology of Person and World (15-32). Martinus Nijhoff Publishers.

Rukgaber, M. S. (2016). The Asymmetry of Space: Kant's Theory of Absolute Space in 1768 . Kantian Review, 21(3), 415-435.

Sanır, F. (2000). Coğrafya Terimleri Sözlüğü. Ankara: Gazi Kitabevi.

Santillana, G. D. (2013). Seçme Metinlerle Rönesans Filozofları. (İ. Yıldız, Çev.). Ankara: Dipnot Yayınları.

Schaefer, F. K. (1953). Exceptionalism in Geography: A Methodological Examination. Annals of the Association of American Geographers, 43(3), 226-249.

Seamon, D., Mugerauer, R. (1985). Dwelling, Place and Enviroment. Leiden: Martinus Nijhoff Publishers.

Smith, N. (2017). Eşitsiz Gelişim: Doğa, Sermaye ve Mekânın Üretimi. (E. Soğancılar, Çev.), İstanbul: Sel Yayıncılık.

Soja, E. W. (2017). Postmodern Coğrafyalar: Eleştirel Toplumsal Teoride Mekânin Yeniden İleri Sürülmesi. (Y. Çetiner, Çev.). İstanbul: Sel Yayıncilık.

Tuan, Y. F. (1971). Geography, Phenomenology and The Study of Human Natura. Canadian Geographer, 3, 181-192.

Tuan, Y. F. (2001). Space and Place: The Perspective of Experience. Minneapolis: University of Minnesota Press.

Üngür, E. (2011). Mekân Kavramının Disiplinerler Arası Tarihsel Değişimi Üzerinden Mimarlık ve Mekân İlişkileri. (Yüksek Lisans Tezi). İstanbul Teknik Üniversitesi, Fen Bilimleri Enstitüsü, İstanbul.

Whitehead, A. N. (2018). Doğa ve Yaşam. (S. Çalc1, Çev.), İstanbul: Öteki Yayınevi.

Witherick, M., Ross, S. \& Small, J. (2011). A Modern Dictionary of Geography. London: Arnold Press.

Zahavi, D. (2020). Fenomenoloji: Illk Temeller. (S. Bayazit, Çev.), İstanbul: Ayrıntı Yayınları. 
